Article

\title{
Analysis of Socio-Hydrological Evolution Processes Based on a Modeling Approach in the Upper Reaches of the Han River in China
}

\author{
Xiaoyu Zhao ${ }^{1}$, Dengfeng Liu ${ }^{1, *} \mathbb{C}$, Xiu Wei ${ }^{1,2}$, Lan Ma ${ }^{1}$, Mu Lin $^{3}$, Xianmeng Meng ${ }^{4}$ and Qiang Huang ${ }^{1}$ \\ 1 State Key Laboratory of Eco-Hydraulics in Northwest Arid Region, School of Water Resources and \\ Hydropower, Xi'an University of Technology, Xi'an 710048, China; zhaoxy@sehemodel.club (X.Z.); \\ weixiu@sehemodel.club (X.W.); malan@sehemodel.club (L.M.); wresh@mail.xaut.edu.cn (Q.H.) \\ 2 Hydrology and Water Resources Bureau of Henan, Yellow River Conservancy Commission, \\ Zhengzhou 450000, China \\ 3 School of Statistics and Mathematics, Central University of Finance and Economics, Beijing 100081, China; \\ mlin@cufe.edu.cn \\ 4 School of Environmental Studies, China University of Geosciences, Wuhan 430074, China; \\ mengxianmeng2000@163.com \\ * Correspondence: liudf@xaut.edu.cn
}

\section{check for} updates

Citation: Zhao, X.; Liu, D.; Wei, X.; Ma, L.; Lin, M.; Meng, X.; Huang, Q. Analysis of Socio-Hydrological Evolution Processes Based on a Modeling Approach in the Upper Reaches of the Han River in China. Water 2021, 13, 2458. https:// doi.org/10.3390/w13182458

\section{Academic Editors:}

Timos Karpouzoglou

and Pankaj Kumar

Received: 20 July 2021

Accepted: 6 September 2021

Published: 7 September 2021

Publisher's Note: MDPI stays neutral with regard to jurisdictional claims in published maps and institutional affiliations.

Copyright: (C) 2021 by the authors Licensee MDPI, Basel, Switzerland. This article is an open access article distributed under the terms and conditions of the Creative Commons Attribution (CC BY) license (https:/ / creativecommons.org/licenses/by/ $4.0 /)$.

\begin{abstract}
The Han River is the water source of the South-to-North Water Diversion Project and the "Han River to Wei River Water Diversion Project" in China. In order to ensure that the water quality and quantity are sufficient for the water diversion project, the natural forest protection project, river chief system and other measures have been implemented in the Han River by the government. At the same time, several large reservoirs have been built in the Han River basin and perform the functions of water supply and hydropower generation, which is an important type of clean power. Under the influence of human activities, the coupling interaction between humans and water in the upper reach of the Han River drives the socio-hydrological evolution process. In this study, from the perspective of socio-hydrology, a model of socio-hydrological evolution (SHE) in the Han River in southern Shaanxi was built to simulate the potential evolution path of the socio-hydrological system and determine possible measures for the sustainable governance of the river basin. By adjusting the model parameters, four future scenarios were established: natural continuation, economic development, environmental protection and industrial adjustment scenarios. Taking 2018 as the base year, the evolution of socio-hydrology in the upper reaches of the Han River was predicted under the four scenarios from 2019 to 2045 . The simulation results show that: (1) In the entire study area, except for domestic water, the water consumption of other departments show an upward or stable trend. There are differences in water consumption changes in the upper and lower sections, which are related to the different socio-economic conditions. (2) Comparing different development scenarios, the industrial adjustment and environmental protection scenarios are superior to the other scenarios. Natural continuation and economic development scenarios appear to be unfavorable for the sustainability of water resources and the economy. (3) In addition, based on the development scenarios, some policy suggestions are put forward, such as reducing the irrigation water quota, appropriately adjusting the industrial structure and promoting the growth of the urban population and the development of urbanization.
\end{abstract}

Keywords: socio-hydrology; evolution model; system dynamics; scenario analysis; Han River basin

\section{Introduction}

The period of the industrial revolution is known as the Anthropocene, during which humans have changed the Earth on an unprecedented scale [1]. Human beings directly or indirectly change the land water cycle by intercepting rivers, transferring water across river basins and discharging wastewater into rivers [2,3]. In addition, changes in hydrological 
characteristics also cause changes in the ecosystem [4]. The connections between people and water systems are highly complex [5]. Several concepts, such as virtual water [6], the water footprint [7] and water value stream [8], attempt to combine humans and hydrology. Water is not only the core element of the ecological and environmental system but also a strategic resource for the development of human society and the economy. Fresh water supply and water quality are the key factors that affect and constrain human living, food production and economic growth. However, a growing number of signals, ranging from declining groundwater levels and deteriorating lake water quality to the disappearance of wetlands, indicate that current water system use is unsustainable $[9,10]$, and the decline in water resources has been compounded by urbanization and population growth [11]. With the expanding human footprint in the hydrological cycle, it is clear that humans need to adapt their activities to water systems to achieve co-evolution $[12,13]$. The study of human-water co-evolution has long attracted the attention of researchers $[14,15]$. In 2012, after summarizing previous studies, Sivapalan first proposed the definition of sociohydrology [16], which has since become an independent hydrologic discipline. At the same time, he encouraged a broader view of socio-hydrological systems in the context of socio-environmental systems.

Subsequently, the discussion of socio-hydrology has gradually intensified. Coupled systems are not limited to social and hydrological subsystems but often involve ecological subsystems as well. Firstly, the study of socio-hydrology focuses on building a theoretical framework. Elshiafei established a general conceptual framework for a socio-hydrological model applicable to agriculture and selected some general proxy indicators for different model modules, such as water quality change, vegetation change and bird species abundance, to represent ecological service functions [17]. In addition, human activities such as coal mining and reservoir operation have a significant impact on the hydrological process in basins $[18,19]$. Reservoir operation was modeled with the river ecohydrological process, and the demands of different types of hydropower stations on the river discharge were studied [20]. Subsequently, researchers attempted to establish a conceptual socio-hydrological model by describing regional socio-hydrological mechanisms using equations and by introducing socio-economic variables. Di Baldassarre explored the interaction between human settlements and flooding [21]. Srinivasan developed a human-hydrodynamic model in India [22]. Van Emmerik developed a conceptual model of the relationship between society and hydrology in river basins with extensive irrigation [23]. The co-evolution of humans and water in the Tarim River Basin of China was analyzed from a socio-hydrologic perspective using the Taiji-Tire Model, and Liu established a human-water co-evolutionary coupling model for the Tarim River Basin [24,25]. Lu used sentiment analysis to assess the cooperation needs of various countries and established a socio-hydrological model of trans-boundary river cooperation (TCSH model) to simulate the cooperation and conflict observed in the Lancang-Mekong River Basin [26]. Halder used social-hydrological approach to predict groundwater demand in different sectors of the Sundarbans [27]. Kumar analyzed the water scarcity on three very large river islands in Asia, and advocates that socio-hydrological research should focus on how to improve the adaptability of the vulnerable coastal island communities [28].

Studies on the socio-hydrological coupling system mainly adopt evolution models. The socio-hydrological models generally use dynamic equations to describe the process of evolution. Compared with the objective optimization model, which can only simulate the stable state of the system, the social hydrological model is based on process simulation. Thus, the socio-hydrological model can simulate the evolution process of the system under a changing environment and can be used to study the evolution of the socio-hydrological system, also known as the socio-hydrological evolution model. The models mainly include the system dynamics model (SDM), the agent-based model (ABM) and system of systems (SoS) [29]. The agent-based model (ABM) is mainly used to estimate the loss of human life and property in the event of environmental collapse [30,31]. Due to the need to predict the subject behavior of each person in the event of a disaster, the performance of the ABM 
is poor in the face of more complex socio-hydrological processes [32,33]. Some scholars established the SOS biofuel model to realize the interaction between humans and water in the context of the National Biofuel Policy [34,35]. The system model needs to consider not only the relationship between environment, policy and water quality but also the various subsystems involved in biofuel development (hydrology, economics, transport, refining and agriculture) [36]. Because the scale is large and the computational complexity is high, it is difficult to grasp and generalize. The SDM is based on the use of a feedback loop and time delay to simulate the co-evolutionary process of the system. The coupling simulation can be carried out using the MATLAB (MathWorks, Natick, MA, USA) and Vensim (Ventana Systems, Inc., Harvard, MA, USA) software packages as a visual platform, which makes the model easy to calculate and generalize [37].

The SDM is a qualitative and quantitative method for system integration simulation analysis, which can estimate changes in a complex system with time [38]. The system dynamics model, also known as the stylized model, can use a series of discrete or continuous equations to represent the change in state variables [39,40]. EI-Gafy established a model with a series of discrete equations to analyze the water footprint and virtual water balance of wheat production and consumption in Egypt [41]. Feng established several continuous forms of joint difference equations to analyze the co-evolution among water supply, power generation and the environment in the context of reservoir operation and interest preference. In this study, a water quantity equation was established based on the system dynamics method to simulate the evolution of the socio-hydrological system in the upper reach of the Han River in China [42].

During the last 10 years, there have been several studies on the socio-hydrological system [43]. By reviewing the research progress in social hydrology, several researchers have reported that the coupling scale, quantization method and system sensitivity are key factors that introduce challenges to the coupling of the social eco-hydrological system [29,44,45]. The spatial scale of ecological and hydrological systems is the river basin, while that of the social system is the administrative region; the time scale of socio-economic data is a year, while that of hydrological and meteorological data is usually a month or day. Therefore, conversion between different spatial and time scales is a problem that should be addressed. In this study, in order to overcome the problem of converting time and space scales, the watershed boundary was matched with the administrative unit scale when dividing the research area, which is more conducive to collecting accurate demographic and socio-economic data. Then, the collected social, hydrological and meteorological data were unified into the annual time scale. In addition, quantifying factors in the social system, such as socio-economic, population and environmental variables, is also a problem that needs to be addressed in the modeling process [46]. In the modeling of socio-hydrological models, the main limitation is that the models are often not accurate due to the uncertainty in input parameters and the process description [47]. On the other hand, the distribution of relevant data in socio-hydrology is very small, and it is difficult to completely reconstruct historical socio-hydrological processes from these data. The limitation of using data-driven methods is that causality cannot be easily determined through empirical data alone [48]. However, in many cases, despite the uncertainty in the data, hydrological and social data are generally more reliable and provide a better understanding of socio-hydrological processes than numerical models [49]. Therefore, considering the advantages and disadvantages of models and data, socio-hydrological modeling studies usually use statistical data to calibrate and validate models. However, in the face of complex system models, researchers need to strike the right balance between generality, accuracy and authenticity [50]. It is worth mentioning that Feng et al. established comprehensive equations and introduced many parameters [39], which are very useful for reshaping the socio-hydrological process in the past and for future development. The policy implications of the simulated results are discussed to provide suggestions for the future development of the study area. This study aims to establish a socio-hydrological evolution (SHE) model to simulate the potential evolution path of the socio-hydrological system in the upper reach of the Han River in China, 
demonstrate the capability of the system dynamics model in socio-hydrological modeling and determine possible measures for the sustainable governance of the river basin. The remainder of this paper is organized as follows. The study area, description of the input data and the model are introduced in Section 2. Sections 3 and 4 present the construction and testing of the socio-hydrological model. Section 5 analyzes the future evolution of the system by setting different scenarios according to the current development situation. Section 6 presents the simulation results and some suggestions for the development of the study area. Finally, conclusions are drawn in Section 7.

\section{Study Area and Data}

\subsection{Study Area}

The Han River, the largest tributary of the Yangtze River, flows through Shaanxi and Hubei provinces. The main stream is $1577 \mathrm{~km}$ long, with a basin area of $159,000 \mathrm{~km}^{2}$ and average annual water resources of 56.6 billion $\mathrm{m}^{3}$. Over 2700 reservoirs have been built along the river, including Shiquan Reservoir, Ankang Reservoir and Danjiangkou Reservoir. The construction of seven cascade hydropower plants is planned in Shaanxi Province, and five of them have been built or are under construction.

The study area is located in the upper reach of the Han River in Shaanxi Province of China, mainly including Hanzhong City, Ankang City and some counties of Shangluo City. The study area is about $51,833 \mathrm{~km}^{2}$, accounting for $82.75 \%$ of the area of the Han River basin in Shaanxi Province. According to the distribution of the river network, the study area is divided into two sections, shown by red lines in Figure 1: the upper section is the upstream catchment of Shiquan hydrological station, and the lower section is the catchment between Shiquan hydrological station and Baihe hydrological station.

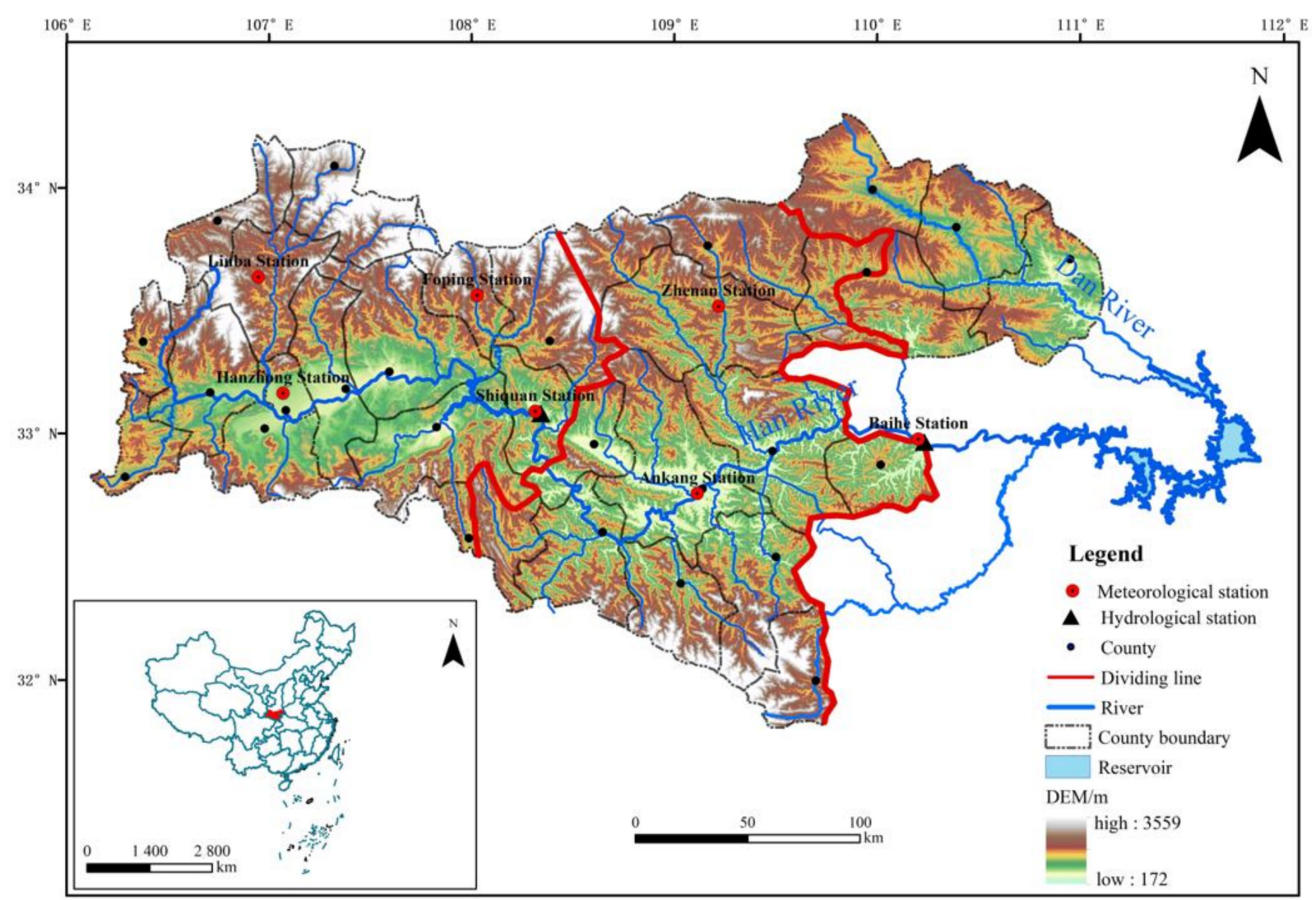

Figure 1. Map of the upper reach of Han River Basin.

The social system is an important component of the SHE system. From 1990 to 2018, the total population of the study area increased from 6.28 million to 6.84 million, and 
the urbanization rate increased from $15.68 \%$ to $26.88 \%$. With the rapid development of the social economy in the upper reach of the Han River, regional water consumption is constantly increasing. From 2001 to 2018, the water consumption of Ankang and Hanzhong increased from 2.083 billion $\mathrm{m}^{3}$ to 2.418 billion $\mathrm{m}^{3}$ (http://slt.shaanxi.gov.cn, accessed on 20 July 2021). Social systems affect the other two SHE systems. The development of the social economy is accompanied by pollution of the ecological environment, and the annual pollution emissions of the two cities increased from 78 million tons to 107 million tons (http:/ / slt.shaanxi.gov.cn, accessed on 20 July 2021). The expansion of urbanization has led to a reduction in the area of cultivated land, with the study area decreasing from 520,000 hectares in 1990 to 370,000 hectares in 2018. Water pollution has led to the deterioration of river water quality, which, in turn, has triggered changes in the classification and structural function of the biome in the upper reach of the Han River [51,52]. In response to the deterioration of the ecological environment, the government implements macro-control policies. Moreover, rainfall and runoff in the upper reach of the Han River have been decreasing since 1980, while evaporation has been increasing [53]. Human activities and climate change are the main factors affecting runoff change in the upper reaches of the Han River $[54,55]$. The reduction in rainfall and runoff leads to less regional inflow and restricts social development. Therefore, the conflict between humans and water in the Han River basin is prominent, the interaction between humans and water is highly complex, and the social, ecological and hydrological systems form feedback loops. In the ever-changing environment, it is necessary to conduct coupling simulations among social, ecological and hydrological systems in the upper reaches of the Han River.

\subsection{Data}

The data include hydrological and meteorological data, land use data and population and socio-economic development data $[53,56]$. The potential evaporation and precipitation data (1980-2018) in the Upper section were obtained by using the weighted average of the four meteorological stations: Hanzhong, Liuba, Foping and Shiquan stations. The weighted average values of Shiquan, Ankang and Zhenan stations were used to obtain the precipitation and potential evaporation data (1980-2018) in the Lower section. Runoff data (1956-2018) were collected from Shiquan and Baihe hydrological stations, and the missing data from 2000 to 2005 at Baihe hydrological station were interpolated by the rainfall-runoff relation. Land use data (2001-2014) were extracted from MCD12Q1 remote sensing data from MODIS (https: / /ladsweb.modaps.eosdis.nasa.gov/search/, accessed on 20 July 2021). Demographic and socio-economic development data (1990-2018) were derived from the Shaanxi Statistical Yearbook, Shaanxi Regional Yearbook, Ankang Yearbook, Shangluo Yearbook, Hanzhong Yearbook, Xi'an Statistical Yearbook and Baoji Yearbook.

\section{Socio-Hydrological Evolution Model Based on System Dynamics}

We establish a socio-hydrological evolution model (SHE model) that can capture the evolutionary trajectory of coupled human-water systems. The SHE model based on system dynamics in the Han River describes the causal relationship among variables in the system, as shown in Figure 2, and then formulates the mathematical expression of system dynamics; that is, it constructs equations. The model framework consists of three main parts: the water consumption module, evaporation module and water balance module. There are three modules in the upper and lower sections, and each module contains the same variables, including state variables, rate variables, auxiliary variables and so on. There is no upstream inflow in the Upper section, and the outflow in the upper section is the inflow in the lower section. The outflow in the lower section is the runoff observed by the Baihe hydrological station. At the annual time scale, the socio-hydrological model constructed in this study uses the water balance equation to describe the key interactions in the complex system. Vensim PLE 8.2.1 software (https: / / vensim.com/, accessed on 20 July 2021) was used to build the model. 


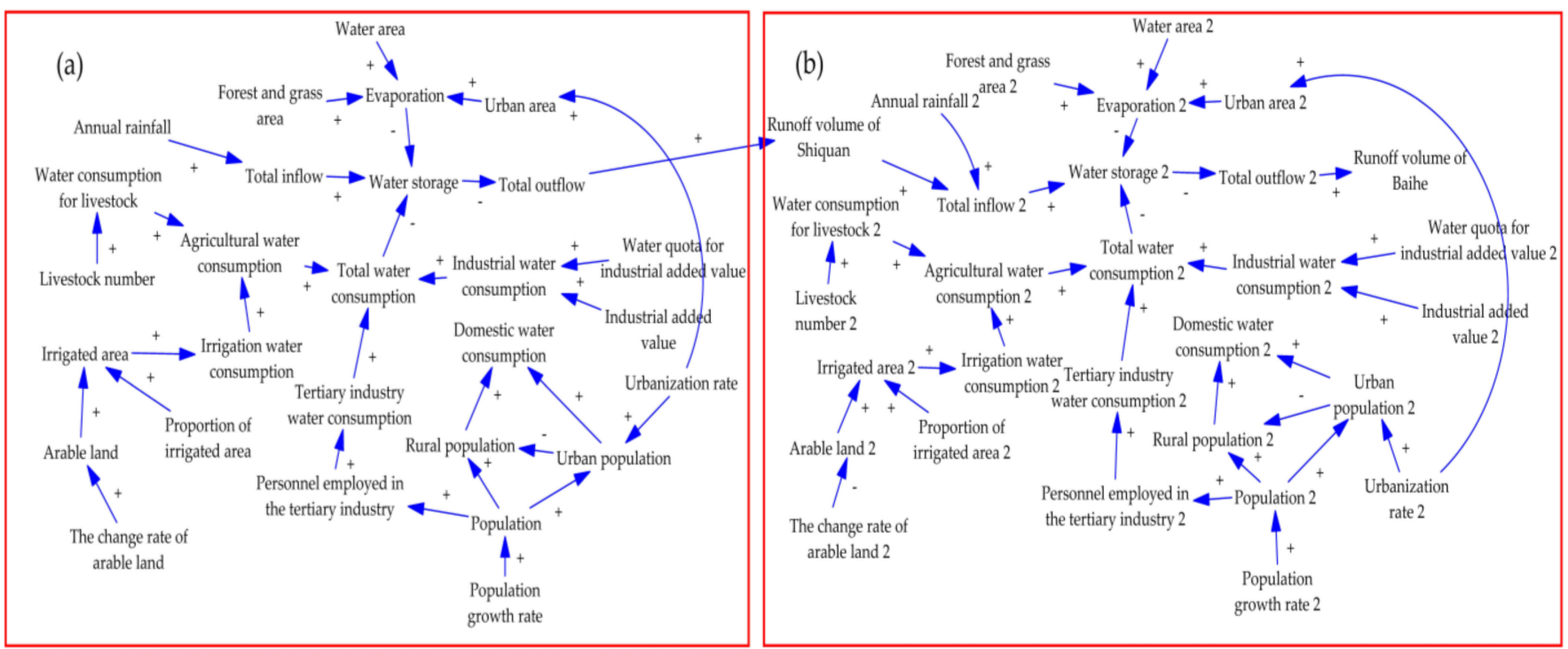

Figure 2. Causal loop diagram of socio-hydrological system: (a) the Upper section; (b) the Lower section.

\subsection{Governing Equations}

The governing equations of the socio-hydrological system in the upper reach of the Han River are the water balance, population, socio-economic and water quota equations, which represent the hydrology, society, economy and policy subsystems, respectively. The subscript " $U$ " represents the upper section, and the subscript " $L$ " represents the lower section. See Appendix A Table A1 for the definitions and symbols of the variables in the model.

\subsubsection{Water Balance Equation}

With reference to Feng et al.'s research [39], we assumed that the study area is a closed system. The water storage is recharged by inflow, consumed by domestic use, agriculture, industry and so on, and finally released downstream. In addition, referring to Liu et al.'s method of calculating evaporation [25], evaporation was added to the water balance.

The water balance of each section is:

$$
\begin{array}{ll}
S_{U, t}= & S_{U, t-1}+I_{U}-O_{U}-E_{U}-W_{U} \\
S_{L, t} & =S_{L, t-1}+I L_{L-} O_{L}-E_{L}-W_{L}
\end{array}
$$

where $S_{U, t}$ oration in the Upper section, and the subscript $t$ (year) represents time. The definitions of these variables in the Lower section are similar to those in the Upper section, so only the notation of the Upper $I_{U}$ :

$$
\begin{array}{ll}
I_{U}= & P_{\text {URAIN }} \times A_{U} \\
I_{L}= & P_{\text {LRAIN }} \times A_{L}+O_{U}
\end{array}
$$

where $P_{\text {URAIN }}(\mathrm{mm})$ and $P_{\text {LRAIN }}(\mathrm{mm})$ are the rainfall in the Upper and Lower sections, and $A_{U}\left(\mathrm{~km}^{2}\right)$ and $A_{L}\left(\mathrm{~km}^{2}\right)$ are the areas of the Upper and Lower sections. The outflow $(O)\left(\mathrm{m}^{3}\right)$ is related to the inflow $(I)$, evaporation $(E)$ and water storage $(S)$. The formula of the inflow is shown in the latter section.

The actual evapotranspiration formulas are:

$$
\begin{gathered}
E_{U}=E_{U G F}+E_{U U}+E_{U W} \\
E_{U G F}=f\left(A_{U G F}, E_{U P}\right)=A_{U G F} \times \alpha_{U G F} \times E_{U P} \\
E_{U U}=f\left(A_{U U}, E_{U P}\right)=A_{U U} \times \alpha_{U U} \times E_{U P} \\
E_{U W}=f\left(A_{U W}, E_{U P}\right)=A_{U W} \times \alpha_{U W} \times E_{U P}
\end{gathered}
$$


where $E_{U P}(\mathrm{~mm})$ is the annual potential evaporation in the Upper section. $A_{U G F}\left(\mathrm{~km}^{2}\right)$, $A_{U U}\left(\mathrm{~km}^{2}\right)$ and $A_{U W}\left(\mathrm{~km}^{2}\right)$ are the grass and forest area, the urban area and the water area in the Upper section. $E_{U G F}\left(\mathrm{~m}^{3}\right), E_{U U}\left(\mathrm{~m}^{3}\right)$ and $E_{U W}\left(\mathrm{~m}^{3}\right)$ are the grass and forest evaporation, the urban evaporation and the water evaporation in the Upper section. $\alpha_{U G F}$, $\alpha_{U U}$ and $\alpha_{U W}$ are the empirical coefficients.

The water consumption formula is:

$$
W_{U}=W_{U A}+W_{U D}+W_{U I}+W_{U E}+W_{U T}
$$

where $W_{U A}\left(\mathrm{~m}^{3}\right), W_{U D}\left(\mathrm{~m}^{3}\right), W_{U I}\left(\mathrm{~m}^{3}\right), W_{U E}\left(\mathrm{~m}^{3}\right)$ and $W_{U T}\left(\mathrm{~m}^{3}\right)$ are the agricultural, domestic, industrial, environmental and tertiary industry water consumption in the Upper section. Water consumption is calculated by the quota method, and the equations are shown in Appendix A Tables A2 and A3.

\subsubsection{Social Equation}

The Malthus population prediction model was used to predict the population in the upper reach of the Han River. This model regards the population growth rate as a constant. Based on the population in the base year, the annual population is predicted by calculating the statistical population growth trend:

$$
P_{t}=P_{0} \times\left(1+r_{P}\right)^{n}
$$

where $P_{t}$ is total population, $r_{P}$ is the natural rate of population change, $n$ is the year number, and $P_{0}$ is the base year population.

\subsubsection{Economic Equation}

Industrial added value, cultivated land area, livestock quantity, hospital beds and tertiary industry employees are used to represent the economic scale of the community. Cultivated land area, livestock quantity and hospital beds were predicted by the constant growth rate method or the constructed constitutive equation, which can be seen in Appendix A Tables A2 and A3.

The logistic model was used to predict the industrial added value $\left(V_{A I, t}\right)$. The formula is:

$$
V_{A I, t}=\frac{V_{A I, \max }}{1+\left(\frac{V_{A I, \max }}{V_{A I, 0}} e^{-r_{V A I} \times\left(t-t_{0}\right)}\right)}
$$

where $r_{V A I}$ is the change rate of industrial added value, $V_{A I, \max }$ is the maximum industrial added value that the environment can accommodate, and $V_{A I, 0}$ is the initial value.

\subsubsection{Water Quota Equation}

In this study, the water quota method was used to calculate the water consumption of each industry. Since 2010, water consumption per 10,000 yuan (Chinese yuan) of GDP and water consumption per 10,000 yuan of industrial added value have been used as important indicators of China's energy management. Water consumption per 10,000 yuan of industrial added value was selected to estimate industrial water consumption. The quotas of industrial added value water and irrigation water are from "Shaanxi Province Water Resources Bulletin" (http:/ / slt.shaanxi.gov.cn/, accessed on 20 July 2021). The water quota per 10,000 yuan of industrial added value shows a decreasing trend. According to historical observation data, the DOSERESP model with the S-shaped curve can be appropriately adjusted to simulate the water quota for industrial added value $\left(q_{V I A}\right)$ :

$$
q_{V I A}=A_{1}+\frac{A_{2}-A_{1}}{1+10^{\left(t_{0}-t\right) p}}
$$

where $A_{1}$ is the minimum value, $A_{2}$ is the maximum value, $t_{0}$ is the center point, and $p$ is the growth rate. 
The quota of irrigation water $\left(q_{W I}\right)$ has no obvious trend, and the measured values are used as input data. It is assumed that the quota of irrigation water from 1990 to 2005 is the same as that in 2006, and the irrigation water quota for future scenarios is the same as that in 2018. The other water quotas slightly change according to "Norm of water intake for industries of Shaanxi Province (DB61/T943-2020)", as shown in Table 1.

Table 1. The value of water quota.

\begin{tabular}{|c|c|c|c|}
\hline Water Quota & Variable & Unit & Value \\
\hline $\begin{array}{l}\text { Water quota for rural } \\
\text { population }\end{array}$ & $q_{R P}$ & $\mathrm{~m}^{3} /$ per & 29.20 \\
\hline $\begin{array}{l}\text { Water quota for urban } \\
\text { population }\end{array}$ & $q u P$ & $\mathrm{~m}^{3} /$ per & 47.45 \\
\hline Water quota for hospital beds & $q_{H B}$ & $\mathrm{~m}^{3} /$ bed & 60.23 \\
\hline $\begin{array}{l}\text { Water quota for tertiary } \\
\text { industry employees }\end{array}$ & $q_{T P}$ & $\mathrm{~m}^{3} /$ per & 36.50 \\
\hline Water quota for cows & $q_{\mathrm{COW}}$ & $\mathrm{m}^{3} /$ per & 29.20 \\
\hline Water quota for sheep & $q_{S H E E P}$ & $\mathrm{~m}^{3} /$ per & 3.65 \\
\hline Water quota for pigs & $q_{P I G}$ & $\mathrm{~m}^{3} /$ per & 12.78 \\
\hline
\end{tabular}

\subsection{Constitutive Relationship}

The constitutive relationship, which is established through historical data, is an equation that quantifies the internal causality among variables and is also the decisive factor driving the co-evolution of the socio-hydrological system. A total of 42 constitutive equations were established for the model. At present, a method that can determine the functional relationships between variables of the system scientifically, universally and accurately has not been proposed. Sivapalan and Blöeschl point out that the functional relationships can be estimated using intuition, through data analysis (if the appropriate data exist), from related studies or based on consensus principles [40]. These methods were used in our study. According to Jia's method [57], constitutive equations can be divided into two categories: in Class I, the simulation variables of the constitutive model are established based on the growth rate or time based on historical data (in Appendix A Table A2), and in Class II (in Appendix A Table A3), the constitutive relationship is estimated based on observation data or experts, combined with modeling purposes, model calibration and other relevant variables. In this study, the focus is on the estimation of the Class II constitutive relationship. For example, the outflow is controlled by the inflow, evaporation and water storage. When the inflow and water storage are large, the outflow released to the downstream area is large; when the evaporation is large, the outflow released to the downstream area is small. Domestic water consumption is determined by the population and its water quota. When one of these variables-the population or its water quota-increases while the other remains unchanged, the water consumption increases.

\section{Calibration and Validation of Socio-Hydrological Evolution Model}

Based on the current situation of the development and utilization of water resources in the upper reaches of the Han River, this study adopted the prototype framework proposed by Elshafei et al. [17] for socio-hydrological modeling and the general steps of socio-hydrological modeling proposed by Sivapalan and Blöschl [40]. The causality relationship among social, ecological and hydrological subsystems within the region is taken as the core to establish the equations, and the subsystems are coupled by the principle of system dynamics, which is consistent with some previous methods for establishing socio-hydrological models [42,57], to formulate a socio-hydrological model and simulate the evolutionary behavior of the system in the upper reaches of the Han River. The variables used as input data are ignored in the diagram in Figure 2. The time step of the model is 1 year. The model divides the study area into two parts (the upstream and down- 
stream parts), adopts Shiquan hydrological station as the boundary and embeds the county boundary in the social system into the watershed scale for scale unification. The equations representing the relationships among the variables in the model quantify the interactions between humans and water in the socio-hydrological system $[21,25,50,58]$.

The simulation period is 1990-2045, in which 1990-2018 is the historical data period, 2019-2045 is the model simulation period, and the simulation time step is 1 year. The historical period (1990-2018) is divided into the calibration period (1990-2009) and the validation period (2010-2018). The initial values of the main variables are shown in Table 2, which are estimated based on historical data.

Table 2. The initial values of the main variables and calibrated parameters of the evolution model.

\begin{tabular}{|c|c|c|c|c|}
\hline Variables & Variable Description & $\begin{array}{l}\text { Initial Value in Upper } \\
\text { Section }\end{array}$ & $\begin{array}{l}\text { Initial Value in Lower } \\
\text { Section }\end{array}$ & Unit \\
\hline$P$ & Population & $2,885,747$ & $3,211,930$ & per \\
\hline$N_{P I G}$ & Number of pigs & $1,100,000$ & $1,520,090$ & per \\
\hline$N_{S H E E P}$ & Number of sheep & 95,068 & 345,078 & per \\
\hline$N_{\text {COW }}$ & Number of cows & 277,192 & 278,240 & per \\
\hline$V_{I A}$ & Industrial added value & 23,774 & 65,753 & $10^{4}$ yuan \\
\hline$N_{H B}$ & Number of hospital beds & 11,016 & 4500 & bed \\
\hline$A_{G F}$ & Forest and grass area & 20,000 & 18,000 & $\mathrm{~km}^{2}$ \\
\hline$A_{W}$ & Water area & 16.21 & 12.74 & $\mathrm{~km}^{2}$ \\
\hline$A_{U}$ & Urban area & 75 & 25 & $\mathrm{~km}^{2}$ \\
\hline$\alpha_{G F}$ & $\begin{array}{l}\text { Empirical coefficient of forest and } \\
\text { grass evaporation }\end{array}$ & 0.7 & 0.6 & - \\
\hline$\alpha_{E}$ & $\begin{array}{l}\text { Empirical coefficient of environmental } \\
\text { water consumption }\end{array}$ & 0.008 & 0.008 & - \\
\hline$\alpha_{U}$ & $\begin{array}{l}\text { Empirical coefficient of urban } \\
\text { evaporation }\end{array}$ & 0.2 & 0.2 & - \\
\hline$\alpha_{W}$ & $\begin{array}{c}\text { Empirical coefficient of water surface } \\
\text { evaporation }\end{array}$ & 1 & 1 & - \\
\hline$A_{C}$ & Cultivable land area & 219,871 & 297,268 & $\mathrm{~km}^{2}$ \\
\hline$\Delta S$ & Water storage & 130 & 120 & $\mathrm{~m}^{3}$ \\
\hline$E_{P}$ & Potential evaporation & 705.1 & 813.3 & $\mathrm{~mm}$ \\
\hline$\alpha_{I}$ & Proportion of irrigated area & 0.60 & 0.70 & - \\
\hline$V_{I A, \max }$ & Maximum industrial added value & $1.83 \times 10^{7}$ & $2.08 \times 10^{7}$ & $10^{4}$ yuan \\
\hline$r_{U P}$ & Urbanization rate & 0.1568 & 0.0904 & - \\
\hline
\end{tabular}

According to the causality and equation of the model, the parameters that need to be calibrated in the model include the change rate of the population $\left(r_{P}\right)$, the change rate of the urbanization rate $\left(r_{R U}\right)$, the change rate of cultivated land area $\left(r_{C}\right)$, the change rate of cows $\left(r_{C O W}\right)$, the growth rate of industrial added value $\left(r_{V I A}\right)$ and the water quota change rate of industrial added value $\left(r_{q V I A}\right)$. The variables that are validated by historical data include total population $(P)$, urban population $\left(P_{U}\right)$, cultivated land area $\left(A_{C}\right)$, the number of cows $\left(N_{C O W}\right)$, industrial added value $\left(V_{I A}\right)$ and industrial added value water quota $\left(q_{V I A}\right)$. In addition, the equations for the numbers of pigs and sheep $\left(N_{S H E E P}, N_{P I G}\right)$ are fitted by historical data, and there are no parameters to calibrate. The potential evaporation $\left(E_{P}\right)$ and the annual precipitation are input data. The values of calibration parameters are shown in Table 3, and the evaluation results in the calibration and validation periods are shown in Tables 4 and 5. Mean Absolute Percentage Error (MAPE), Nash-Sutcliffe 
efficiency coefficient (NSE) and the coefficient of determination $\left(\mathrm{R}^{2}\right)$ are used to evaluate the variables simulated by the model. When NSE is 1, the simulated value equals the observed value.

Table 3. The parameter settings of the evolution model.

\begin{tabular}{cccc}
\hline Variables & Variable Name & Upper Section & Lower Section \\
\hline$r_{P}$ & Change rate of population & 0.0026 & 0.0036 \\
\hline$r_{R U}$ & Change rate of urbanization rate & 0.0032 & 0.0041 \\
\hline$r_{C}$ & Change rate of cultivated land & -0.01 & -0.014 \\
\hline$r_{C O W}$ & Change rate of cows & -0.0046 & -0.003 \\
\hline$r_{V I A}$ & Change rate of industrial added value & 0.17 & 0.22 \\
\hline$r_{q V I A}$ & Change rate of the quota for industrial added value & -0.128 & -0.149 \\
\hline
\end{tabular}

Table 4. The evaluation results in the calibration period (1990-2009).

\begin{tabular}{ccccccc}
\hline & \multicolumn{3}{c}{ Upper Section } & \multicolumn{3}{c}{ Lower Section } \\
\hline Variables & MAPE (\%) & NSE & $\mathbf{R}^{\mathbf{2}}$ & MAPE (\%) & NSE & $\mathbf{R}^{\mathbf{2}}$ \\
\hline$P$ & 0.40 & 0.92 & 0.97 & 0.63 & 0.88 & 0.95 \\
\hline$P_{U}$ & 2.25 & 0.96 & 1.00 & 6.63 & 0.90 & 0.99 \\
\hline$A_{C}$ & 5.70 & 0.64 & 0.94 & 5.76 & 0.96 & 0.93 \\
\hline$N_{\text {COW }}$ & 4.98 & 0.23 & 0.75 & 9.58 & 0.13 & 0.59 \\
\hline$N_{\text {SHEEP }}$ & 27.41 & 0.77 & 0.84 & 19.72 & 0.77 & 0.84 \\
\hline$N_{\text {PIG }}$ & 12.10 & 0.55 & 0.62 & 13.56 & 0.62 & 0.60 \\
\hline$V_{\text {IA }}$ & 24.92 & 0.98 & 0.99 & 17.99 & 1.00 & 0.99 \\
\hline$q_{\text {VIA }}$ & 9.38 & 0.98 & 0.99 & 14.90 & 0.98 & 0.99 \\
\hline$R_{\text {Shiquan }}$ & 16.75 & 0.69 & 0.91 & & & 0.96 \\
\hline$R_{\text {Baihe }}$ & & & & 6.82 & 0.91 &
\end{tabular}

Table 5. The evaluation results in the validation period (2010-2018).

\begin{tabular}{ccccccc}
\hline \multicolumn{3}{c}{ Upper Section } & \multicolumn{3}{c}{ Lower Section } \\
\hline Variables & $\begin{array}{c}\text { MAPE } \\
\mathbf{( \% )}\end{array}$ & NSE & $\mathbf{R}^{\mathbf{2}}$ & $\begin{array}{c}\text { MAPE } \\
\mathbf{( \% )}\end{array}$ & NSE & $\mathbf{R}^{\mathbf{2}}$ \\
\hline$P$ & 0.89 & 0.87 & 0.80 & 0.43 & 0.95 & 0.11 \\
\hline$P_{U}$ & 4.05 & 0.93 & 1.00 & 11.64 & 0.86 & 0.97 \\
\hline$A_{C}$ & 2.93 & 0.84 & -0.71 & 6.86 & 0.83 & 0.31 \\
\hline$N_{\text {COW }}$ & 3.68 & 0.29 & 0.58 & 6.99 & 0.32 & 0.18 \\
\hline$N_{\text {SHEEP }}$ & 6.88 & 0.88 & -0.04 & 13.57 & 0.75 & -0.21 \\
\hline$N_{\text {PIG }}$ & 20.76 & 0.38 & -0.79 & 31.64 & 0.67 & -0.19 \\
\hline$V_{\text {IA }}$ & 32.49 & 0.54 & 0.97 & 32.68 & 0.47 & 0.97 \\
\hline$q_{\text {VIA }}$ & 7.91 & 1.00 & 0.98 & 18.52 & 1.00 & 0.98 \\
\hline$R_{\text {Shiquan }}$ & 25.87 & 0.40 & 0.93 & & & \\
\hline$R_{\text {Baihe }}$ & & & & 20.13 & -0.14 & 0.40 \\
\hline
\end{tabular}

The simulation results in the calibration period are good. Except for the number of cows, the simulation results are better in the calibration period. The simulation performance of livestock $\left(N_{C O W}, N_{S H E E P}, N_{P I G}\right)$ and cultivated land area $\left(A_{C}\right)$ in the validation 
period is poor, and the MAPE of industrial added value is more than $30 \%$. This is because the rapid development of the economy and urbanization led to a sharp decline in the area of cultivated land around 2000; after that, under the influence of national policy regulation, the area of cultivated land was stable and showed a slight upward trend (Figure $3 \mathrm{e}, \mathrm{f}$ ). Cultivated land area was simulated in the validation period according to the change rate in the historical period, so the simulation results are poor. In Section 5, the growth rate of cultivated land area in the simulation period is adjusted according to the actual situation to better reflect the change law in the validation period. According to the irrigation water consumption data published in the Water Resources Bulletin (http://slt.shaanxi.gov.cn/zfxxgk/fdzdgknr/zdgz/, accessed date on 20 August 2021), the simulated irrigation water consumption is in line with the actual situation. The simulation results are reported in Section 6. $N_{C O W}, N_{\text {SHEEP }}$ and $N_{P I G}$ are affected by the fluctuation of prices in the market. The number of cows dropped rapidly in 2007 before rising to average levels in 2010, and then it dropped sharply again in 2018 (Figure 3g,h). At the same time, the fluctuations of the number of pigs and sheep are larger (Figure 3i-l). These variables are greatly affected by external conditions (outside the catchment), so large errors in the validation period are acceptable. In addition, agricultural water consumption consists of livestock water consumption and irrigation water consumption; the proportion of livestock water consumption is small and is not the focus of the model simulation, so it has little impact on the results. The simulation performance of other variables is good. In general, the simulation results of the model are acceptable, and the system dynamics model can be used to analyze the possible trajectories of future co-evolution. The model is a process-based model, and the simulation is driven by external meteorological conditions, i.e., precipitation and potential evaporation. The system does not exhibit any tipping point behavior under average climate conditions.

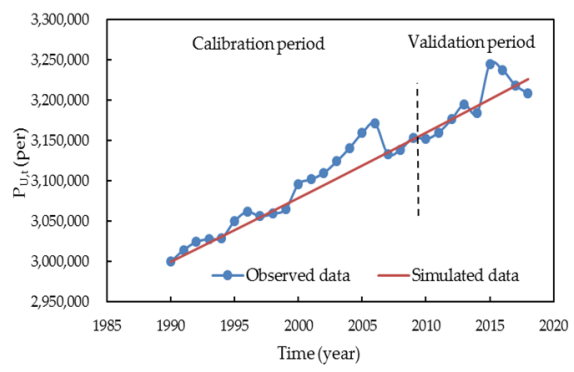

(a)

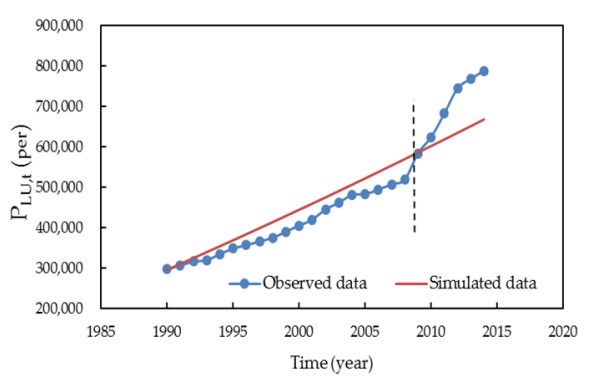

(d)

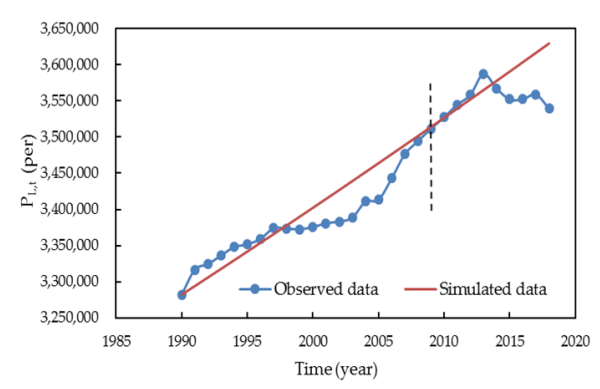

(b)

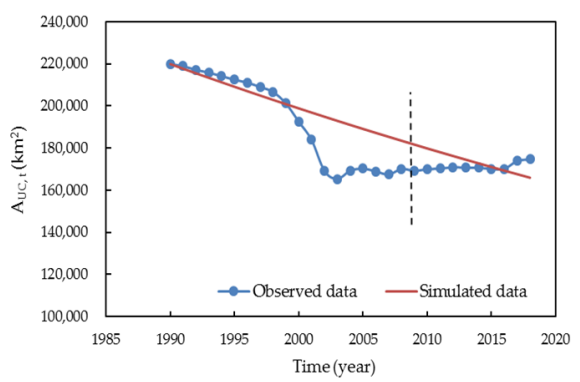

(e)

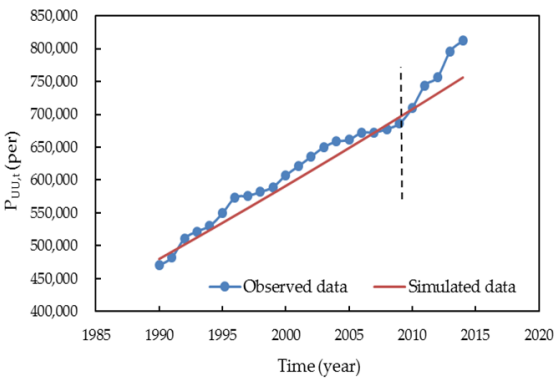

(c)

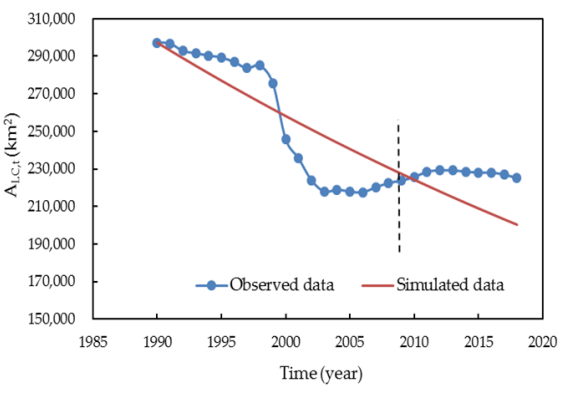

(f)

Figure 3. Cont. 


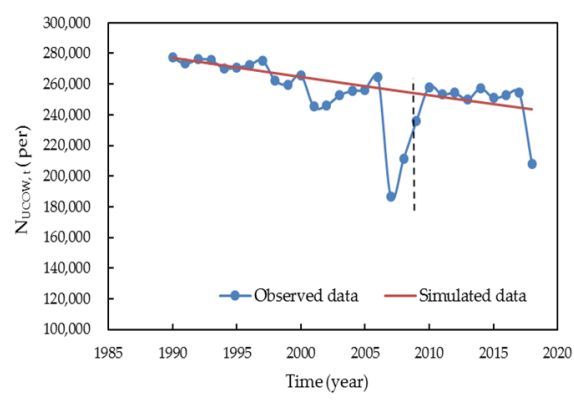

(g)

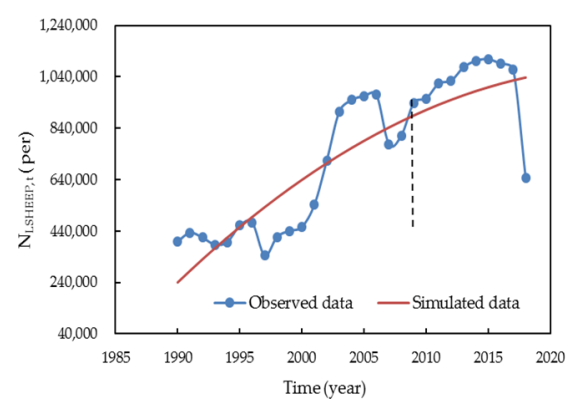

(j)

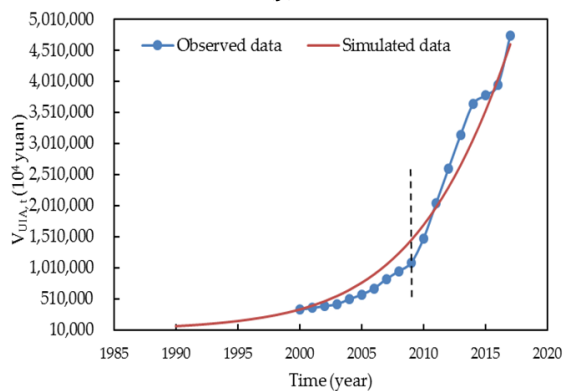

(m)

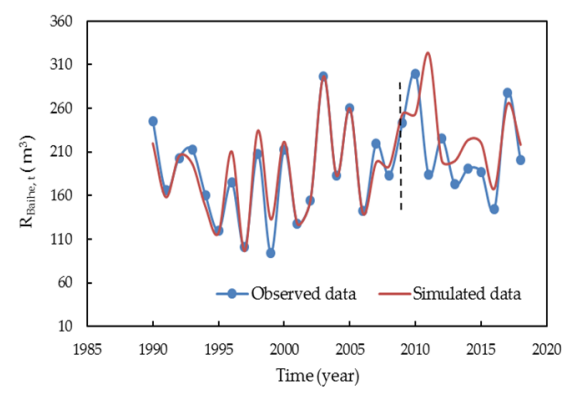

(p)

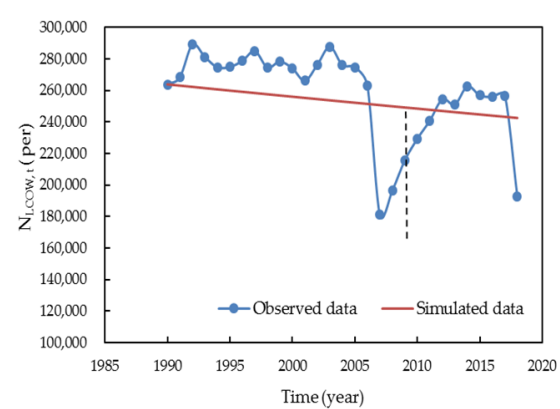

(h)

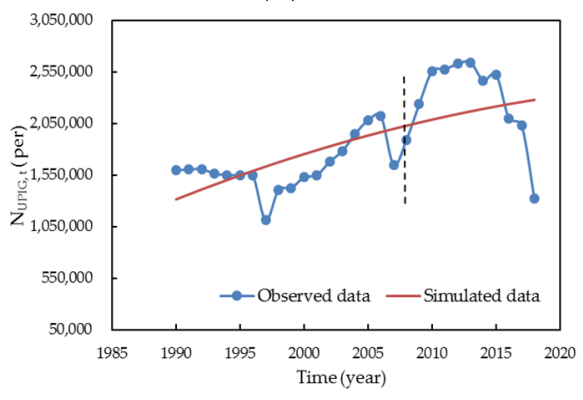

(k)

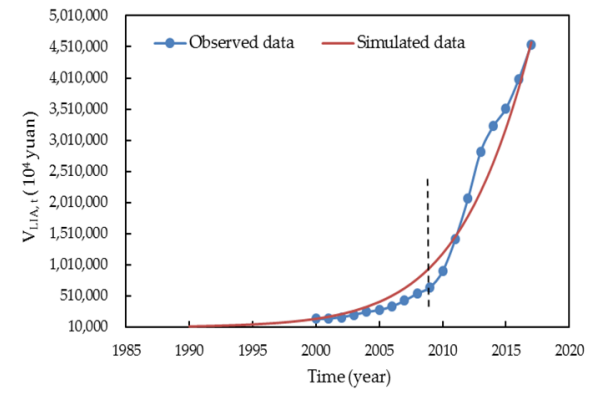

(n)

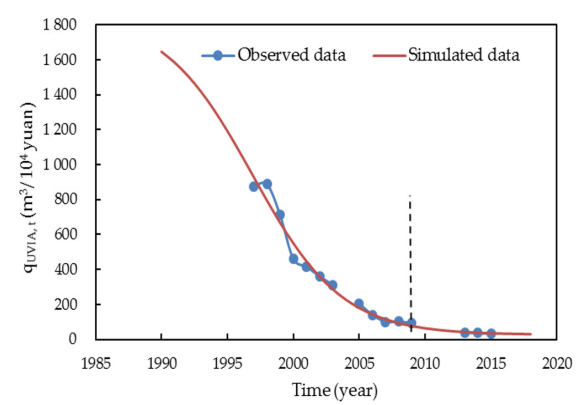

(q)

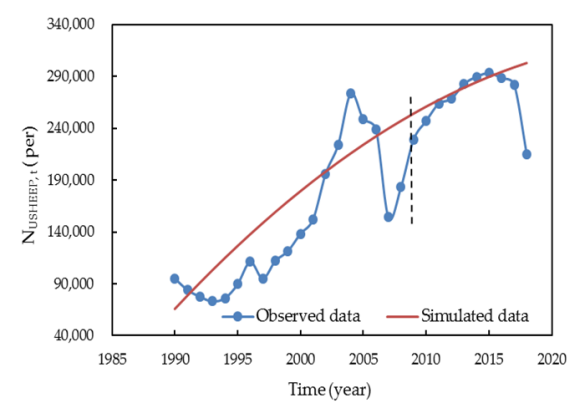

(i)

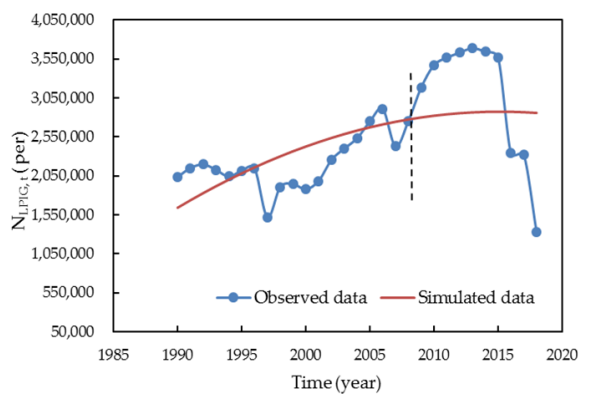

(1)

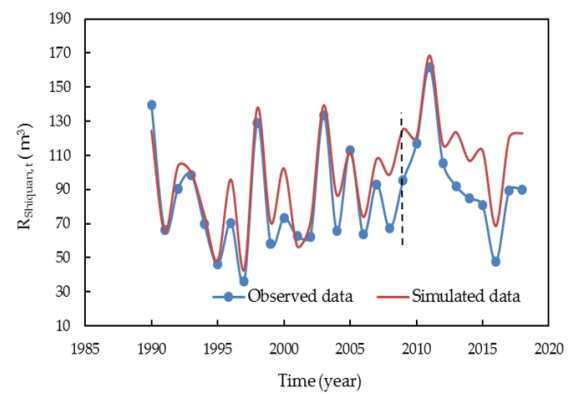

(o)

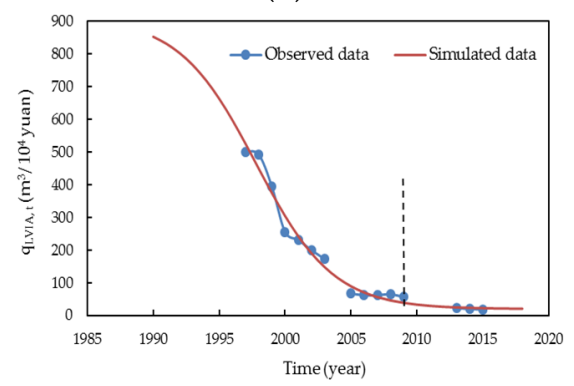

(r)

Figure 3. Simulated and observed values of variables. (a) Population in the upper section, (b) population in the lower section, (c) urban population in the upper section, (d) urban population in the lower section, (e) cultivable land area in the upper section, (f) cultivable land area in the lower section, (g) number of cows in the upper section, (h) number of cows in the lower section, (i) number of sheep in the upper section, (j) number of sheep in the upper section, (k) number of pigs in the upper section, (1) number of pigs in the lower section, (m) industrial added value in the upper section, (n) industrial added value in the upper section, (o) Shiquan runoff in the upper section, (p) Baihe runoff in the lower section, (q) water quota for industrial added value in the upper section, (r) water quota for industrial added value in the lower section. 


\section{Development Scenarios of the Socio-Hydrological System in the Han River}

The study area is a water source protection area. Since 2014, the population in the study area has been declining. According to the Population Development Plan of Shaanxi Province (2016-2030), the urbanization rate of household registration in Shaanxi Province was 39\% in 2015 (http:/ / www.shaanxi.gov.cn, (accessed on 20 August 2021), while the urbanization rate in the study area was only $23.8 \%$ in 2014 , which is low. In the region, agriculture consumes the most water, industrial development is rapid, and the proportion of the tertiary industry is low. This study mainly analyzes changes in regional water use with changes in the population, urbanization and industrial structure. According to the development characteristics and actual conditions of Hanzhong City and Ankang City, six sensitive parameters, namely, urbanization rate, cultivated land area change rate, irrigation water quota, change rate of forest and grassland area, growth rate of industrial added value and the proportion of tertiary industry employees, were selected in both the upper and lower sections in this study. Based on the current base year (2018), these six sensitive parameters were adjusted, and four development scenarios were established: natural continuation, environmental protection, industrial adjustment and economic development.

In the natural continuation scenario, all parameters are set to the values in the base year (2018). In the environment protection scenario, the main goal is to protect the ecology and environment, achieve high-quality and low-speed development of industry and increase the proportion of tertiary industry employees appropriately. In the industrial adjustment scenario, the structure of water use is changed, the urbanization level is maintained at a medium-high speed of development, the growth rate of industrial added value is reduced, and the proportion of the tertiary industry is increased. In the economic development scenario, the main goal is to increase the economic development, so the proportion of urbanization, the growth rate of industrial added value and the urban area increase. Since the hydro-meteorological conditions cannot be adjusted or analyzed through policies, scenario analysis was carried out under the assumption that the hydro-meteorological conditions remain stable. Taking 2018 as the base year, the evolution of the socio-hydrological system from 2019 to 2045 was simulated under the different development scenarios. The values of the sensitive parameters in the study area under the four scenarios are shown in Tables 6 and 7.

Table 6. Sensitive parameter values in the upper section.

\begin{tabular}{cccccc}
\hline Scenario & $r_{\text {URU }}$ & $r_{U C}$ & $r_{U P}$ & $r_{\text {UVIA }}$ & $\alpha_{\text {UTP }}$ \\
\hline Natural continuation scenario & 0.004 & 0.004 & -0.003 & 0.11 & 0.160 \\
\hline Environmental protection scenario & 0.006 & 0.001 & 0.003 & 0.06 & 0.162 \\
\hline Industrial adjustment scenario & 0.008 & -0.003 & 0.003 & 0.09 & 0.12 \\
\hline Economic development scenario & 0.010 & -0.006 & 0.06 & 0.165 \\
\hline
\end{tabular}

Table 7. Sensitive parameter values in the lower section.

\begin{tabular}{cccccc}
\hline Scenario & $r_{L R U}$ & $r_{L C}$ & $r_{L P}$ & $r_{L V I A}$ & $\alpha_{L T P}$ \\
\hline Natural continuation scenario & 0.006 & -0.008 & -0.006 & 0.11 & 0.160 \\
\hline Environmental protection scenario & 0.008 & 0.001 & 0.003 & 0.08 & 0.162 \\
\hline Industrial adjustment scenario & 0.010 & -0.003 & 0.003 & 0.10 & 0.170 \\
\hline Economic development scenario & 0.012 & -0.006 & 0.006 & 0.16 & 0.165 \\
\hline
\end{tabular}

6. Results and Discussion

\subsection{Results}

The simulation results are shown in Figures 4 and 5. In both the upper and lower 
sections, the total water consumption shows an upward trend in all four scenarios. The greatest water consumption is by industrial and agricultural activities, accounting for more than $90 \%$, followed by domestic water consumption, accounting for about $10 \%$; the proportion of environmental water and tertiary industry water is the lowest. Because the parameters adopt the values in the scenarios after 2019, the simulated variables show jumps in Figure 4a,b,g,h and Figure 5a,b,g,h, respectively.

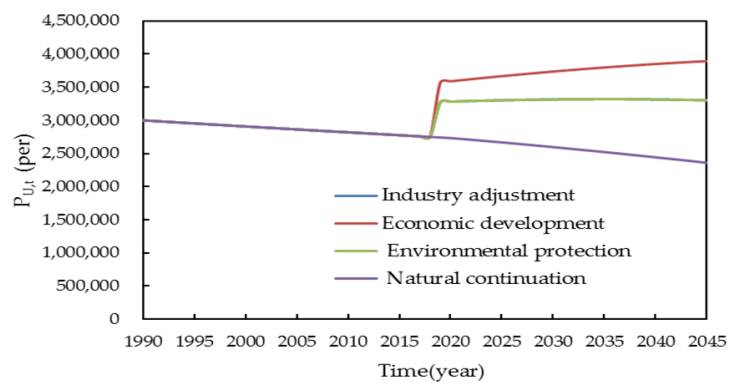

(a)

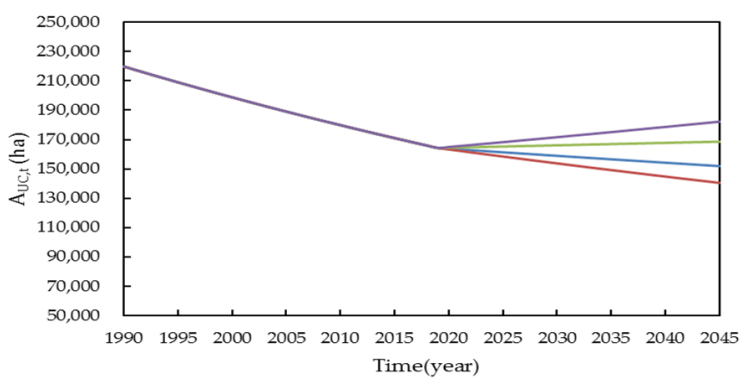

(c)

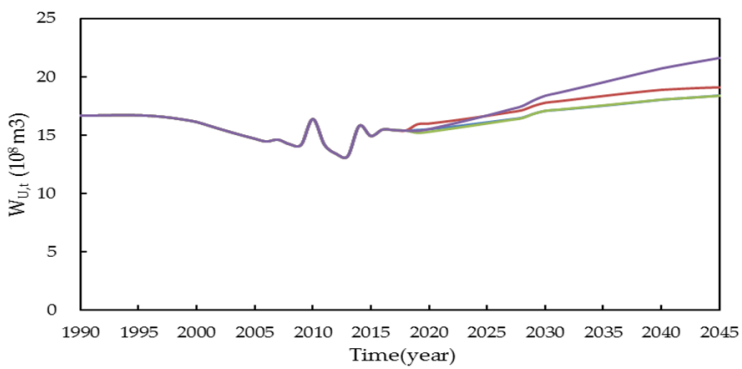

(e)

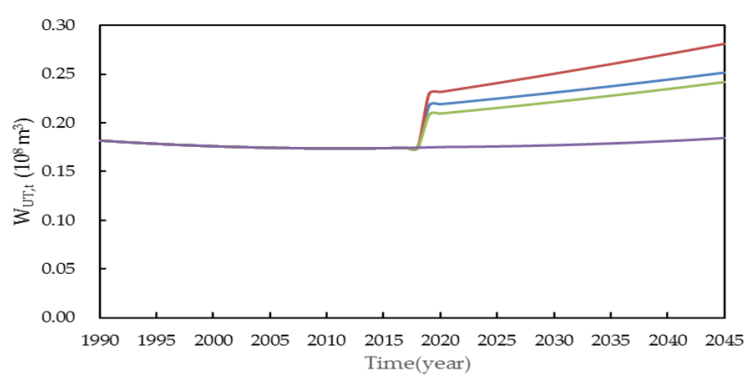

$(\mathrm{g})$

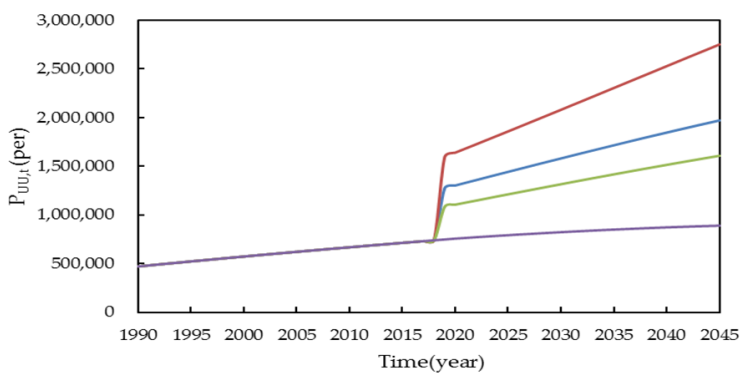

(b)

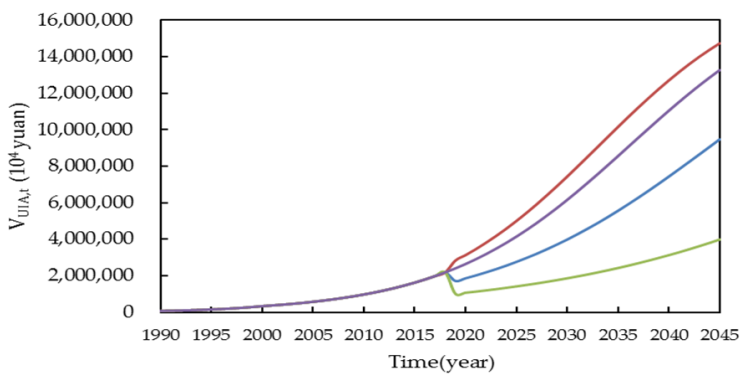

(d)

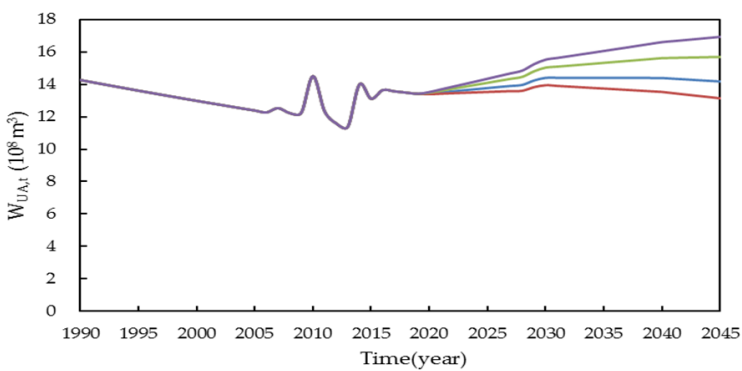

(f)

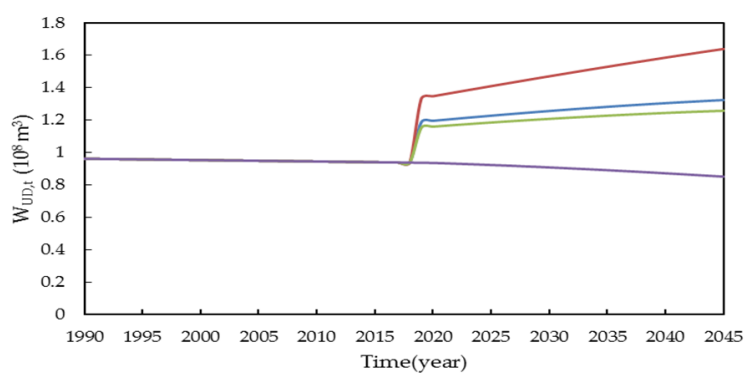

(h)

Figure 4. Cont. 


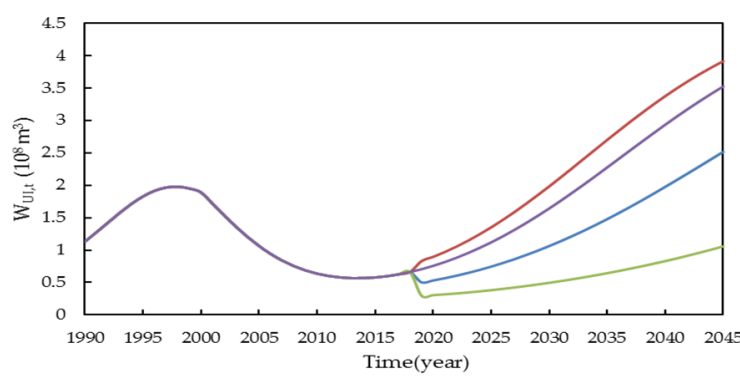

(i)

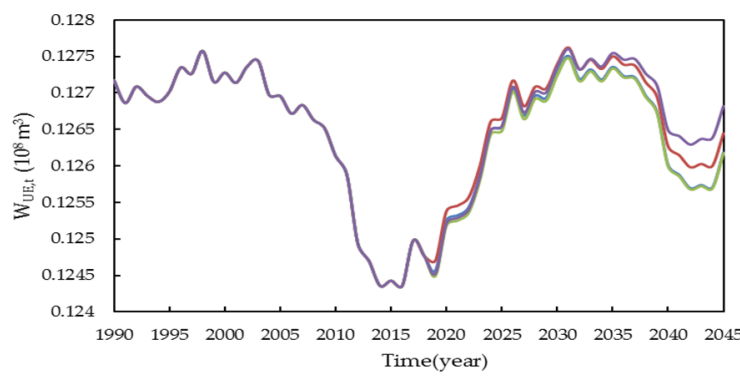

(j)

Figure 4. The future evolution of the main variables in the upper section. (a) Population in the upper section, (b) urban population in the upper section, (c) cultivable land area in the upper section, (d) industrial added value in the upper section, (e) water consumption in the upper section, (f) agricultural water consumption in the upper section, (g) tertiary industry water consumption in the upper section, (h) domestic water consumption in the upper section, (i) industrial water consumption in the upper section, (j) environmental water consumption in the upper section.

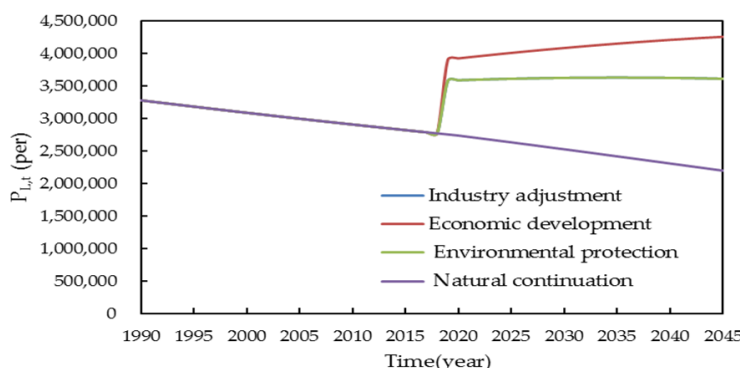

(a)

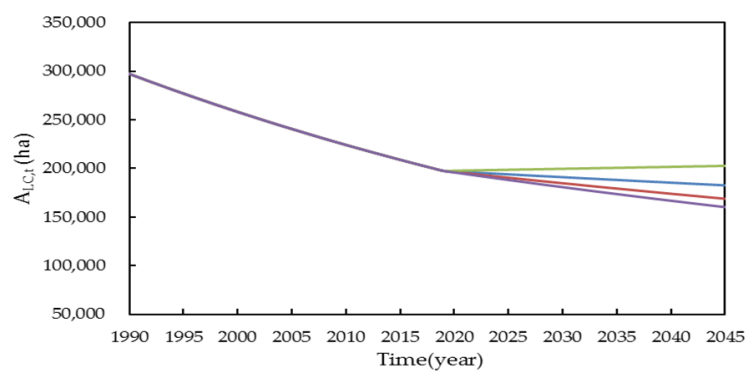

(c)

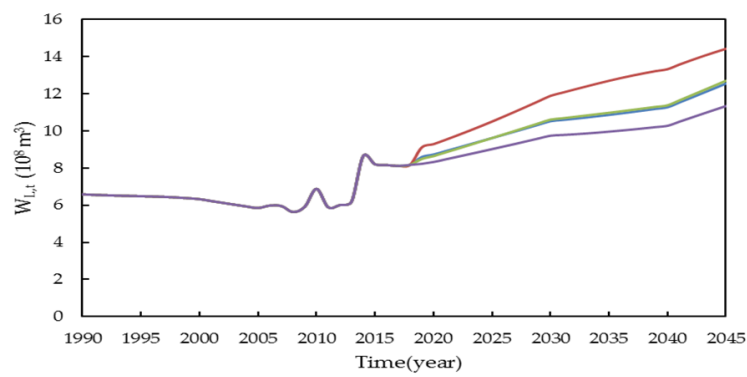

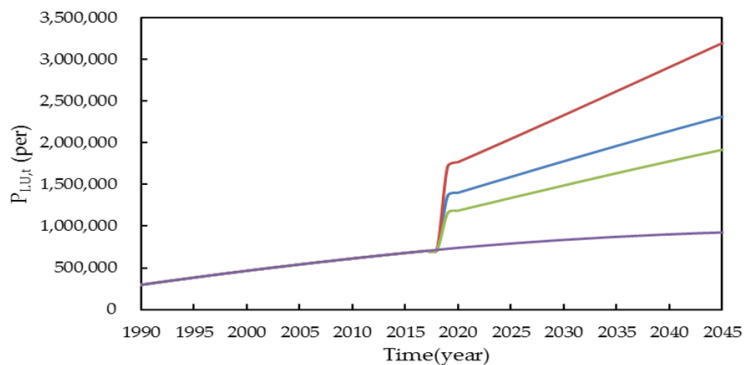

(b)

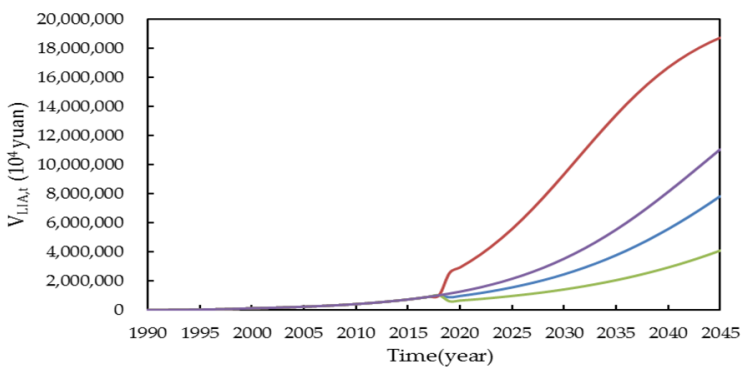

(d)

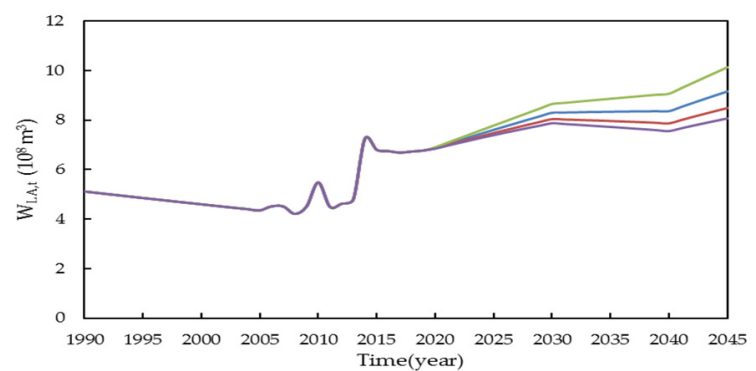

(e)

Figure 5. Cont. 


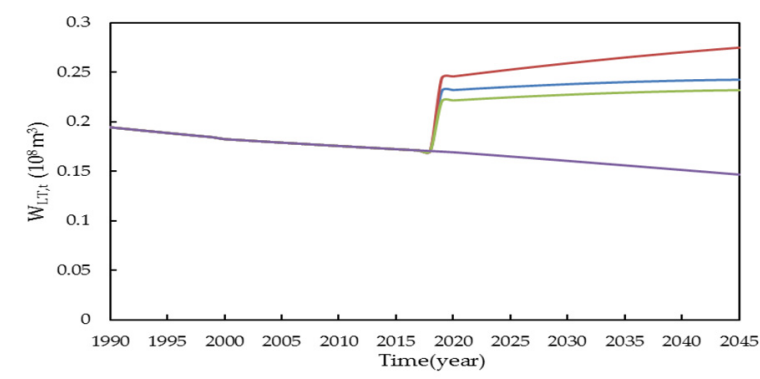

$(\mathrm{g})$

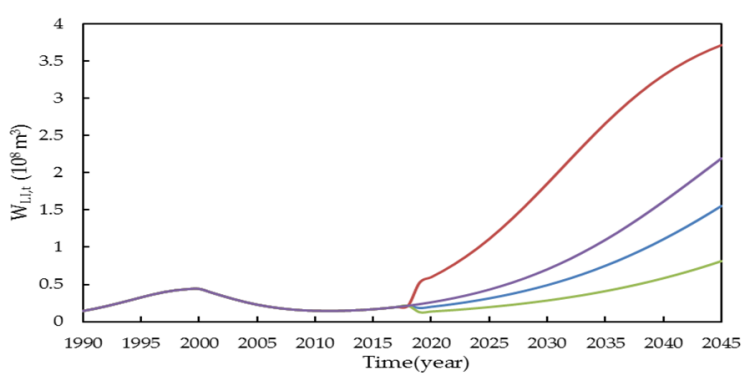

(i)

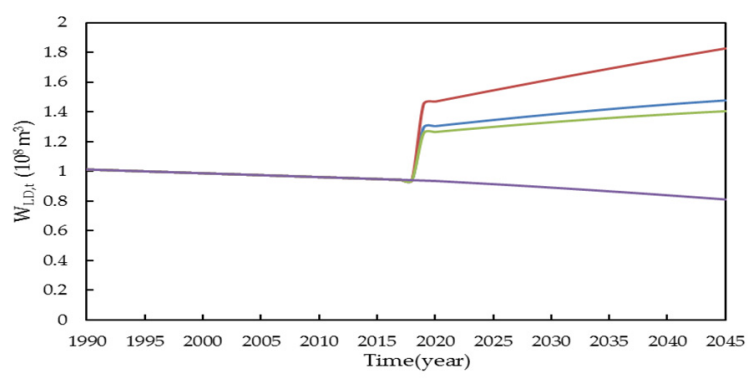

(h)

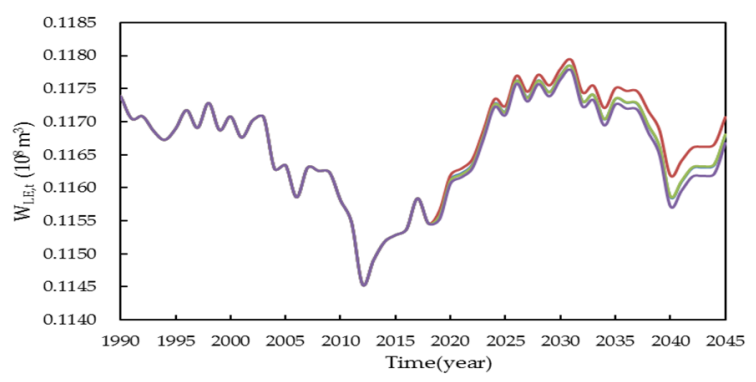

$(\mathbf{j})$

Figure 5. The future evolution of the main variables in the lower section. (a) Population in the lower section, (b) urban population in the lower section, (c) cultivable land area in the lower section, (d) industrial added value in the lower section, (e) water consumption in the lower section, (f) agricultural water consumption in the lower section, (g) tertiary industry water consumption in the lower section, (h) domestic water consumption in the lower section, (i) industrial water consumption in the lower section, (j) environmental water consumption in the lower section.

Figure 4 shows the future evolution path of the main variables in the upper section. As shown in Figure 4a, during the simulation period, the population declines significantly in the natural continuation scenario and slightly increases in the economic development scenario. The population is stable in the environmental protection and industrial adjustment scenarios. The urban population (Figure $4 \mathrm{~b}$ ) shows an increasing trend in the four scenarios. As shown in Figure 4e, the average total water consumption (2019-2045) in the region shows an upward trend. The order of the average total water consumption among scenarios is natural continuation $\left(18.62 \times 10^{8} \mathrm{~m}^{3} /\right.$ year $)>$ economic development $\left(17.74 \times 10^{8} \mathrm{~m}^{3} /\right.$ year $)>$ industrial adjustment $\left(17.05\right.$ billion $\mathrm{m}^{3} /$ year $)>$ environmental protection $\left(17.01 \times 10^{8} \mathrm{~m}^{3} /\right.$ year). Among all water uses, agricultural water consumption (Figure 4f) is the highest, followed by industrial and domestic water consumption, and the tertiary industry and environment water consumption are the lowest. Agricultural water consumption increases significantly under the natural continuity scenario, while it declines under the economic development scenario. The changing trend of agricultural water consumption under different scenarios is the same as that of cultivated land area (Figure 4c). Industrial water consumption increases rapidly, which is consistent with the increasing trend of industrial added value (Figure $4 \mathrm{~d}$ ). In all scenarios, the tertiary industry and environmental water consumption are below $0.3 \times 10^{8} \mathrm{~m}^{3}$.

In the upper section, comparing the values in 2018 and 2045 under different development scenarios shows that: the population drops by $14.17 \%$ in the natural continuation scenario (Figure $4 \mathrm{a}$ ), domestic water consumption drops by $9.21 \%$, cultivated land area increase by $9.83 \%$, and industrial added value increases by about five times. Domestic and tertiary industry water consumption decrease. Agricultural and industrial water consumption increase the most, so the total water consumption is the highest, while the environmental water consumption is the lowest in all scenarios. Under the natural con- 
tinuation scenario, the upper section will face several problems in the future, such as population loss, a low level of urbanization, reduced runoff and an imbalance between the supply and demand of water resources.

Under the economic development scenario, the proportion of industrial water rises from $4.3 \%$ in 2018 to $20.49 \%$ in 2045 , and the cultivated land area decreases the most (by $15.34 \%$ ). The water consumption increases by $24.05 \%$, which is less than the total water use in the natural continuation scenario. Long-term development of this scenario may lead to a shortage of cultivated land resources, which will limit the development of agriculture.

In the environmental protection scenario, the water consumption in the upper section is the lowest among the four scenarios. In this scenario, the cultivated land shows a stable and slightly rising trend, and the level of economic development is low.

In the industrial adjustment scenario, the tertiary industry water consumption has a clear upward trend, while the proportion of agricultural water consumption drops by $10 \%$; however, agriculture still consumes the most water. The urban population and industrial added value are higher than those in the environmental protection scenario, and the cultivated land area decreases by $8.44 \%$. Water consumption in the industrial adjustment scenario is slightly higher than that in the environment protection scenario.

Figure 5 shows the future evolution path of the main variables in the lower section. In the four future scenarios, the total water consumption in the region shows an upward trend. The order of total water consumption among scenarios is economic development $\left(11.94 \times 10^{8} \mathrm{~m}^{3} /\right.$ year $)>$ environmental protection $\left(10.57 \times 10^{8} \mathrm{~m}^{3} /\right.$ year $)>$ industrial adjustment $\left(10.51 \times 10^{8} \mathrm{~m}^{3} /\right.$ year $)>$ natural continuation $\left(9.71 \times 10^{8} \mathrm{~m}^{3} /\right.$ year $)$. The ranking of scenarios according to total water consumption differs between the lower and upper sections. The current water consumption in the lower section is lower than that in the upper section. In the lower section, the changing trends of the population, urban population, industrial added value, tertiary industry personnel, domestic water consumption, tertiary industry water consumption and industrial water consumption are the same as those in the upper section. The cultivated land area is the lowest in the natural continuation scenario. Compared with the historical period, the cultivated land area in the simulation period is reduced by $27.5 \%$, and the agricultural water consumption is the lowest. In all scenarios, the domestic water consumption in the upper section is higher than that in the lower section during the simulation period, because the population in the lower section is larger than that in the upper section. The rest of the water consumption in the upstream area is higher than that in the lower section.

In the lower section, comparing the values in 2018 and 2045 under different development scenarios indicates that: in the natural continuation scenario, the population and cultivated land area markedly decrease, and the urbanization and industrial levels are low, so the water consumption is the lowest among the four scenarios. In the economic development scenario, the most prominent features are the rapid increase in the population, industrial added value and urbanization rate. The proportion of industrial water consumption increases from $2.64 \%$ to $25.82 \%$, and the proportion of agricultural water consumption drops from $82.36 \%$ to $58.85 \%$ in 2045 . In the industrial adjustment and environmental protection scenarios, urbanization and industrialization development are moderate, and the cultivated land area increases by $1.20 \%$ only in the environmental protection scenario. The water consumption in the industrial adjustment scenario is lower than that in the economic development scenario and higher than that in the natural continuation scenario: this is because agriculture consumes the largest amount of water, and the cultivated land area drastically decreases in the natural continuation scenario, so the agricultural water consumption is much lower than in other scenarios. The tertiary industry and environmental water consumption proportions increase but remain at low levels.

\subsection{Implications}

Based on the analysis and comparison of the evolution paths of the socio-hydrological system in the four scenarios, and combined with research on regional policies and planning, 
the following suggestions are put forward to achieve sustainable development in the Han River basin in southern Shaanxi:

(1) Improve agricultural irrigation technology and reduce the irrigation water quota. The study area is dominated by agricultural water consumption. In 2018, the proportion of agricultural water consumption in the upper section was $87.7 \%$, and that in the lower section was $82.4 \%$, so reducing agricultural water consumption can effectively reduce water consumption. The Chinese government and the Shaanxi provincial government have issued the "strictest farmland protection policy" and included cultivable land area protection as a target in the government assessment $[59,60]$. In order to control agricultural water consumption while protecting the cultivable land area, the irrigation water quota should be reduced. Under the natural continuation scenario, water consumption in the upper and lower sections in 2045 is predicted to be $21.61 \times 10^{8} \mathrm{~m}^{3}$ and $11.34 \times 10^{8} \mathrm{~m}^{3}$, respectively. As shown in Table 8 , with other conditions remaining unchanged and the irrigation water quota reduced by $5 \%, 10 \%$, $15 \%$ and $20 \%$, the water consumption in the upper section will be reduced by $3.8 \%$, $7.7 \%, 11.5 \%$ and $15.3 \%$, respectively, and that in the lower section will be reduced by $3.4 \%, 6.9 \%, 10.3 \%$ and $13.8 \%$, respectively, by 2045 . The reduction in the irrigation water quota depends on the development of irrigation technology, which can also promote the further development of modern agriculture.

(2) Accelerate the development of urbanization. According to the "13th Five-Year" Plan of Shaanxi Province, the target value of the urbanization rate in 2020 was $45 \%$, and the actual value was $48.5 \%$ [61]. According to scenario analysis, the urbanization rate of the study area is the highest in the economic development scenario and would be about $30 \%$ in 2020. The urbanization development rate of southern Shaanxi in the Han River basin is relatively low. Therefore, the urbanization process should be accelerated. Furthermore, the transformation of the rural to urban population is conducive to the restoration of forest and grassland [62].

(3) Adjust the industrial structure appropriately. In 2015, the proportion of GDP from the tertiary industry in the Han River basin in southern Shaanxi was $35.78 \%$, and the simulation found that the tertiary industry water consumption in the study area accounted for $1.47 \%$ of the total water consumption. In the industrial adjustment scenario, if the industrial development speed is appropriately reduced and the proportion of tertiary industry personnel is increased, then the total water consumption will significantly decrease. Therefore, the adjustment of the industrial structure should be accelerated to encourage the development of the tertiary industry due to its low water consumption and high output value.

Table 8. The water consumption in 2045 after changing water quota for irrigation.

\begin{tabular}{ccc}
\hline Conditions & Upper Section $\left.\mathbf{( m}^{\mathbf{3}}\right)$ & Lower Section $\left.\mathbf{( m}^{\mathbf{3}}\right)$ \\
\hline $0.95 \times q_{U I}$ & $20.78 \times 10^{8}$ & $10.94 \times 10^{8}$ \\
\hline $0.90 \times q_{U I}$ & $19.96 \times 10^{8}$ & $10.55 \times 10^{8}$ \\
\hline $0.85 \times q_{U I}$ & $19.13 \times 10^{8}$ & $10.16 \times 10^{8}$ \\
\hline $0.80 \times q_{U I}$ & $18.30 \times 10^{8}$ & $9.77 \times 10^{8}$ \\
\hline
\end{tabular}

\section{Conclusions}

In this study, a socio-hydrological model for the upper reaches of the Han River in Shaanxi province of China was established by using the system dynamics method. The main variables representing the population, socio-economic development and hydrological changes were selected to establish the governing equations. The evolution of the water quota for industrial added value, which reflects technology development in industries and agriculture, was simulated using the model. The model was calibrated and validated by historical data of the upper reaches of the Han River. The simulated evolution processes 
reproduced the historical processes of the socio-hydrological system. After the calibration of the model, four scenarios, i.e., natural continuation, economic development, environment protection and industrial adjustment, were established, and the future evolution process of the socio-hydrological system in these four scenarios was analyzed.

According to the evolution analysis of the future scenarios, the population in the study area is declining, and the level of urbanization development is low. Water consumption rises in the four scenarios, and the proportion of agricultural and industrial water is more than $90 \%$. The population loss is rapid in the natural continuation scenario. In the economic development scenario, industrial water consumption increases rapidly, but urban land occupies cultivable land, which is not conducive to agricultural development. If the river basin appropriately improves the level of urbanization and the speed of industrial development, then the industrial adjustment scenario is the best. If cultivated land resources are to be protected, then water consumption in the region should be strictly controlled, and the environmental protection scenario is the best. The simulation results of the four scenarios also provide a reference for water resource management in this region. Policymakers can formulate development policies to carry out macro-control and find a balance between economic development and environmental protection.

The socio-hydrological evolution model based on the system dynamics method was able to simulate the evolution process of the socio-hydrological system, and constitutive equations were established to couple factors representing social development and the hydrometeorology. The model provides a tool for understanding the potential development paths of socio-hydrology in the upper reaches of the Han River.

The socio-hydrological system is a complex system under the comprehensive influence of natural and social factors at different scales. In the present socio-hydrological model in the upper reaches of the Han River, the social and economic modules are only described by a few key variables, and dynamic descriptions of policy changes, environmental awareness and technological development level are lacking, so this is a preliminary simplified model. In future research, the model will be refined by applying a targeted approach, and the physical mechanism of the model will be improved.

Author Contributions: Conceptualization, methodology, and model developed by X.Z., D.L. and X.W.; validation and formal analysis conducted by X.Z., D.L. and X.W.; original draft prepared by X.Z.; review and editing carried out by D.L., L.M., M.L., and X.M.; and supervision supported by Q.H. All authors have read and agreed to the published version of the manuscript.

Funding: This work was partially supported by the National Natural Science Foundation of China (NSFC) (Grant Nos. 51779203, 51609270, 51979252) and State Key Laboratory of Eco-hydraulics in Northwest Arid Region (Grant No. 2019KFKT-4). The authors thank the editor and anonymous reviewers for their constructive comments.

Institutional Review Board Statement: Not applicable.

Informed Consent Statement: Not applicable.

Data Availability Statement: Land use data were extracted from MCD12Q1 of MODIS (https: / / ladsweb.modaps.eosdis.nasa.gov / search/, accessed on 20 July 2021). All of yearbooks are publicly published. The other data presented in this study are available on reasonable request from the corresponding author.

Conflicts of Interest: The authors declare no conflict of interest. 


\section{Appendix A}

Table A1. Variables and parameters used in the model.

\begin{tabular}{|c|c|c|c|c|}
\hline Description & $\begin{array}{l}\text { Symbol in Upper } \\
\text { Section }\end{array}$ & $\begin{array}{c}\text { Symbol in Lower } \\
\text { Section }\end{array}$ & Unit & Type \\
\hline Agricultural water & $W_{U A}$ & $W_{L A}$ & $\mathrm{~m}^{3}$ & Variable \\
\hline Tertiary industry employees & $\alpha_{U T P}$ & $\alpha_{L T P}$ & - & Variable \\
\hline Cultivable land area & $A_{U C}$ & $A_{L C}$ & ha & Variable \\
\hline Domestic water consumption & $W_{U D}$ & $W_{L D}$ & $\mathrm{~m}^{3}$ & Variable \\
\hline $\begin{array}{l}\text { Environmental water } \\
\text { consumption }\end{array}$ & $W_{U E}$ & $W_{L E}$ & $\mathrm{~m}^{3}$ & Variable \\
\hline Forest and grass area & $A_{U G F}$ & $A_{\text {LGF }}$ & $\mathrm{km}^{2}$ & Variable \\
\hline Forest and grass evaporate & $E_{U G F}$ & $E_{L G F}$ & $\mathrm{~m}^{3}$ & Variable \\
\hline Industrial added value & $V_{U I A}$ & $V_{L I A}$ & $10^{4} /$ yuan & Variable \\
\hline $\begin{array}{l}\text { Industrial water } \\
\text { consumption }\end{array}$ & $W_{U I}$ & $W_{L I}$ & $\mathrm{~m}^{3}$ & Variable \\
\hline Inflow & $I_{U}$ & $I_{L}$ & $\mathrm{~m}^{3}$ & Variable \\
\hline Irrigation water consumption & $W_{U N}$ & $W_{U N}$ & $\mathrm{~m}^{3}$ & Variable \\
\hline Livestock water consumption & $W_{U L S}$ & $W_{L L S}$ & $\mathrm{~m}^{3}$ & Variable \\
\hline Number of cows & $N_{\text {UCOW }}$ & $N_{\text {LCOW }}$ & per & Variable \\
\hline Number of sheep & $N_{U S H E E P}$ & $N_{L S H E E P}$ & per & Variable \\
\hline Number of pigs & $N_{U P I G}$ & $N_{L P I G}$ & per & Variable \\
\hline Outflow & $O_{U}$ & $O_{L}$ & $\mathrm{~m}^{3}$ & Variable \\
\hline Population & $P_{U}$ & $P_{L}$ & per & Variable \\
\hline Potential evaporation & $E_{U P}$ & $E_{L P}$ & $\mathrm{~mm}$ & Variable \\
\hline Precipitation & $P_{\text {URAIN }}$ & $P_{\text {LRAIN }}$ & $\mathrm{mm}$ & Variable \\
\hline Proportion of irrigated area & $\alpha_{U I}$ & $\alpha_{L I}$ & - & Variable \\
\hline Rural population & $P_{U R}$ & $P_{L R}$ & per & Variable \\
\hline Surface water area & $A_{U W}$ & $A_{L W}$ & $\mathrm{~km}^{2}$ & Variable \\
\hline Tertiary industry water & $W_{U T}$ & $W_{L T}$ & $\mathrm{~m}^{3}$ & Variable \\
\hline Urban area & $A_{U U}$ & $A_{L U}$ & $\mathrm{~km}^{2}$ & Variable \\
\hline Urban evaporation & $E_{U U}$ & $E_{L U}$ & $\mathrm{~m}^{3}$ & Variable \\
\hline $\begin{array}{l}\text { Water quota for industrial } \\
\text { added value }\end{array}$ & $q_{U V I A}$ & $q_{L V I A}$ & $\mathrm{~m}^{3} / 10^{4}$ yuan & Variable \\
\hline Catchment area & $A_{U}$ & $A_{L}$ & $\mathrm{~km}^{2}$ & Parameter \\
\hline $\begin{array}{c}\text { Conversion coefficient of } \\
\text { forest and grassland } \\
\text { evaporation }\end{array}$ & $\alpha_{U G F}$ & $\alpha_{L G F}$ & - & Parameter \\
\hline $\begin{array}{l}\text { Conversion coefficient of } \\
\text { urban evaporation }\end{array}$ & $\alpha_{U U}$ & $\alpha_{L U}$ & - & Parameter \\
\hline $\begin{array}{l}\text { Conversion coefficient of } \\
\text { water surface evaporation }\end{array}$ & $\alpha_{U W}$ & $\alpha_{L W}$ & - & Parameter \\
\hline Water quota for cows & $q_{\text {Ucow }}$ & $q_{L C O W}$ & $\mathrm{~m}^{3} /$ per & Parameter \\
\hline Water quota for hospital beds & $q_{U H B}$ & $q_{L H B}$ & $\mathrm{~m}^{3} /$ bed & Parameter \\
\hline $\begin{array}{l}\text { Water quota for the tertiary } \\
\text { industry employees }\end{array}$ & $q_{\text {UTP }}$ & $q_{L T P}$ & $\mathrm{~m}^{3} /$ per & Parameter \\
\hline Water quota for pigs & $q_{\text {UPIG }}$ & $q_{L P I G}$ & $\mathrm{~m}^{3} /$ per & Parameter \\
\hline $\begin{array}{l}\text { Water quota for rural } \\
\text { population }\end{array}$ & qURP & $q_{L R P}$ & $\mathrm{~m}^{3} /$ per & Parameter \\
\hline
\end{tabular}


Table A1. Cont.

\begin{tabular}{ccccc}
\hline Description & $\begin{array}{c}\text { Symbol in Upper } \\
\text { Section }\end{array}$ & $\begin{array}{c}\text { Symbol in Lower } \\
\text { Section }\end{array}$ & Unit & Type \\
\hline Water quota for sheep & $q_{\text {USHEEP }}$ & $q_{\text {LSHEEP }}$ & $\mathrm{m}^{3} /$ per & Parameter \\
\hline $\begin{array}{c}\text { Water quota for urban } \\
\text { population }\end{array}$ & $q_{U U P}$ & $q_{L U P}$ & $\mathrm{~m}^{3} /$ per & Parameter \\
\hline $\begin{array}{c}\text { Change rate of urbanization } \\
\text { rate }\end{array}$ & $r_{U R U}$ & $r_{L R U}$ & - & Parameter \\
\hline $\begin{array}{c}\text { Change rate of cultivated } \\
\text { land }\end{array}$ & $r_{U C}$ & $r_{L C}$ & - & Parameter \\
\hline $\begin{array}{c}\text { Change rate of industrial } \\
\text { added value }\end{array}$ & $r_{U V I A}$ & $r_{L V I A}$ & Parameter \\
\hline $\begin{array}{c}\text { Proportion of employees in } \\
\text { the tertiary industry }\end{array}$ & $r_{U T P}$ & $r_{L T P}$ & - & Parameter \\
\hline
\end{tabular}

Table A2. The constitutive equations of Class I.

\begin{tabular}{|c|c|c|c|}
\hline Variable & Variable Name & Estimated Constitutive Relation & Category \\
\hline$N_{U C O W}$ & Number of cows in the upper section & $N_{U C O W, t}=N_{U C O W, t-1} \times\left(1+r_{U C O W}\right)$ & I \\
\hline$N_{\text {LCOW }}$ & Number of cows in the lower section & $N_{L C O W, t}=N_{L C O W, t-1} \times\left(1+r_{L C O W}\right)$ & I \\
\hline$N_{U P I G}$ & Number of pigs in the upper section & $N_{U P I G, t}=-1252.82 t^{2}+5.11 \times 10^{6} t-5.21 \times 10^{9}$ & I \\
\hline$N_{L P I G}$ & Number of pigs in the lower section & $N_{L P I G, t}=-867.06 t^{2}+3.60 \times 10^{6} t-3.73 \times 10^{9}$ & I \\
\hline$N_{\text {USHEEP }}$ & Number of sheep in the upper section & $N_{U S H E E P, t}=-160.46 t^{2}+6.52 \times 10^{5} t-6.61 \times 10^{8}$ & I \\
\hline$N_{\text {LSHEEP }}$ & Number of sheep in the lower section & $N_{L S H E E P, t}=508.31 t^{2}-2.07 \times 10^{6} t+2.11 \times 10^{9}$ & I \\
\hline$A_{U C}$ & Cultivable land area in the upper section & $A_{U C, t}=A_{U C, t-1} \times\left(1+r_{U C}\right)$ & I \\
\hline$A_{L C}$ & Cultivable land area in the Lower section & $A_{L C, t}=A_{L C, t-1} \times\left(1+r_{L C}\right)$ & I \\
\hline$A_{U I}$ & Irrigation area in the Upper section & $A_{U I}=A_{U C} \times \alpha_{U I}$ & I \\
\hline$A_{L I}$ & Irrigation area in the Lower section & $A_{L I}=A_{L C} \times \alpha_{L I}$ & I \\
\hline$A_{U G F}$ & Grass and forest area in the Upper section & $A_{U G F, t}=A_{U G F, t-1} \times\left(1+r_{U G F}\right)$ & I \\
\hline$A_{L G F}$ & Grass and forest area in the Lower section & $A_{L G F, t}=A_{L G F, t-1} \times\left(1+r_{L G F}\right)$ & I \\
\hline$P_{U T}$ & Tertiary industry employees in the Upper section & $P_{U T}=P_{U} \times \alpha_{U T P}$ & I \\
\hline$P_{L T}$ & Tertiary industry employees in the Lower section & $P_{L T}=P_{L} \times \alpha_{L T P}$ & I \\
\hline$A_{U U}$ & Urban area in the Upper section & $A_{U U}= \begin{cases}75 & r_{U U P} \leq 0.25 \\
r_{U P} \times 300 & r_{U U P}>0.25\end{cases}$ & I \\
\hline$A_{L U}$ & Urban area in the Lower section & $A_{L U}= \begin{cases}75 & r_{L U P} \leq 0.25 \\
r_{L P} \times 200 & r_{L U P}>0.25\end{cases}$ & I \\
\hline$P_{U R}$ & Rural population in the Upper section & $P_{U R}=P_{U}-P_{U U}$ & I \\
\hline$P_{L R}$ & Rural population in the Lower section & $P_{L R}=P_{L}-P_{L U}$ & I \\
\hline$P_{\text {UU }}$ & Urban population in the Upper section & $P_{U U}=P_{U} \times r_{U U P}$ & I \\
\hline$P_{L U}$ & Urban population in the Lower section & $P_{L U}=P_{L} \times r_{L U P}$ & I \\
\hline
\end{tabular}

Table A3. The constitutive equations of Class II.

\begin{tabular}{lccc}
\hline Variable & Variable Name & Estimated Constitutive Relation & Category \\
\hline$O_{U}$ & Outflow in the Upper section & $\begin{array}{c}O_{U}=f\left(I_{U}, E_{U}, \Delta S_{U}\right) \\
\left(I_{U}-E_{U}\right) \times 0.73+\Delta S_{U} \times 0.08\end{array}$ & II \\
\hline$O_{L}$ & Outflow in the Lower section & $\begin{array}{c}O_{L}=f\left(I_{L}, E_{L}, \Delta S_{L}\right) \\
\left(I_{L}-E_{L}\right) \times 0.8+\Delta S_{U} \times 0.18\end{array}$ & $\mathrm{II}$ \\
\hline$W_{U E}$ & Environmental water consumption in the Upper section & $W_{U E}=f\left(S_{U}\right)=0.001 \times\left(130-E X P\left(\alpha_{U E} \times S_{U}\right)\right.$ & $\mathrm{II}$ \\
\hline$W_{L E}$ & Environmental water consumption in the Lower section & $W_{L E}=f\left(S_{L}\right)=0.001 \times\left(120-E X P\left(\alpha_{L E} \times S_{L}\right)\right.$ & $\mathrm{II}$ \\
\hline
\end{tabular}


Table A3. Cont.

\begin{tabular}{|c|c|c|c|}
\hline Variable & Variable Name & Estimated Constitutive Relation & Category \\
\hline$E_{U G F}$ & Grass and forest evaporation in the Upper section & $E_{U G F}=f\left(A_{U G F}, E_{U P}\right)=A_{U G F} \times \alpha_{U G F} \times E_{U P}$ & II \\
\hline$E_{L G F}$ & Grass and forest evaporation in the Lower section & $E_{L G F}=f\left(A_{L G F}, E_{L P}\right)=A_{L G F} \times \alpha_{L G F} \times E_{L P}$ & II \\
\hline EUU & Urban evaporation in the Upper section & $E_{U U}=f\left(A_{U U}, E_{U P}\right)=A_{U U} \times \alpha_{U U} \times E_{U P}$ & II \\
\hline$E_{L U}$ & Urban evaporation in the Lower section & $E_{L U}=f\left(A_{L U}, E_{L P}\right)=A_{L U} \times \alpha_{L U} \times E_{L P}$ & II \\
\hline$E_{U W}$ & Water surface evaporation in the Upper section & $E_{U W}=f\left(A_{U W}, E_{U P}\right)=A_{U W} \times \alpha_{U W} \times E_{U P}$ & II \\
\hline$E_{L W}$ & Water surface evaporation in the Lower section & $E_{L W}=f\left(A_{L W}, E_{L P}\right)=A_{L W} \times \alpha_{L W} \times E_{L P}$ & II \\
\hline$W_{U D}$ & Domestic water consumption in the Upper section & $W_{U D}=f\left(P_{U R}, P_{U U}\right)=P_{U R} \times q_{U R}+P_{U U} \times q_{U U}$ & II \\
\hline$W_{L D}$ & Domestic water consumption in the Lower section & $W_{L D}=f\left(P_{L R}, P_{L U}\right)=P_{L R} \times q_{L R}+P_{L U} \times q_{U U}$ & II \\
\hline$W_{U I}$ & Industrial water consumption in the Upper section & $W_{U I}=f\left(V_{U A I}\right)=V_{U A I} \times q_{U V A I}$ & II \\
\hline$W_{L I}$ & Industrial water consumption in the Lower section & $W_{L I}=f\left(V_{L A I}\right)=V_{L A I} \times q_{L V A I}$ & II \\
\hline$W_{U A}$ & Agricultural water consumption in the Upper section & $W_{U A}=f\left(W_{U N}, W_{U L S}\right)=W_{U N}+W_{U L S}$ & II \\
\hline$W_{L A}$ & Agricultural water consumption in the Lower section & $W_{L A}=f\left(W_{L N}, W_{L L S}\right)=W_{L N}+W_{L L S}$ & II \\
\hline$W_{U N}$ & Irrigation water consumption in the Upper section & $W_{U N}=f\left(A_{U I}\right)=A_{U I} \times q_{U I}$ & II \\
\hline$W_{L N}$ & Irrigation water consumption in the Lower section & $W_{L N}=f\left(A_{L I}\right)=A_{L I} \times q_{L I}$ & II \\
\hline$W_{U L S}$ & Livestock water consumption in the Upper section & $\begin{array}{c}W_{U L S}=f\left(N_{\text {USHEEP }}, N_{U C O W}, N_{\text {UPIG }}\right) \\
=N_{U S H E E P} \times q_{U S H E E P}+N_{U C O W} \times q_{U C O W}+N_{U P I G} \times q_{U P I G}\end{array}$ & G II \\
\hline$W_{L L S}$ & Livestock water consumption in the Lower section & $\begin{array}{c}W_{L L S}=f\left(N_{L S H E E P}, N_{L C O W}, N_{L P I G}\right) \\
=N_{L S H E E P} \times q_{L S H E E P}+N_{L C O W} \times q_{L C O W}+N_{L P I G} \times q_{L P I G}\end{array}$ & II \\
\hline$W_{U T} \mathrm{Te}$ & Tertiary industry water consumption in the Upper section & $\begin{array}{c}W_{U T}=f\left(P_{U T}, N_{U H B}\right)= \\
P_{U T} \times q_{U T P}+N_{U H B} \times q_{U H B}\end{array}$ & II \\
\hline$W_{L T} \quad \mathrm{Te}$ & ertiary industry water consumption in the Lower section & $W_{L T}=f\left(P_{L T}, N_{L H B}\right)=P_{L T} \times q_{L T P}+N_{L H B} \times q_{L H B}$ & II \\
\hline
\end{tabular}

\section{References}

1. Steffen, W.; Crutzen, P.J.; McNeill, J.R. The Anthropocene: Are Humans Now Overwhelming the Great Forces of Nature. AMBIO 2007, 36, 614-621. [CrossRef]

2. Goudie, A.S.; Li, B.; Clark, W.C.; Kates, R.W.; Richards, J.F.; Mathews, J.T.; Meyer, W.B. The earth as transformed by human action; global and regional changes in the biosphere over the past 300 years. For. Ecol. Manag. 1990, 55, 341-342. [CrossRef]

3. Luo, P.; Kang, S.; Zhou, M.M.; Nover, D. Water quality trend assessment in Jakarta: A rapidly growing Asian megacity. PLoS ONE 2019, 14, e0219009. [CrossRef] [PubMed]

4. Zhu, Y.; Luo, P.; Zhang, S.; Sun, B. Spatiotemporal Analysis of Hydrological Variations and Their Impacts on Vegetation in Semiarid Areas from Multiple Satellite Data. Remote Sens. 2020, 12, 4177. [CrossRef]

5. Steffen, W.; Grinevald, J.; Crutzen, P.; Mcneill, J. The Anthropocene: Conceptual and historical perspectives. Philos. Trans. R. Soc. A Math. Phys. Eng. Sci. 2011, 369, 842-867. [CrossRef]

6. Emmett, C.F.; Rogers, P.; Lydon, P.; Wolf, A.T. Water in the Arab World: Perspectives and Prognoses. Geogr. Rev. 1996, 86, 152-154. [CrossRef]

7. Hoekstra, A.Y. Virtual Water Trade: Proceedings of the International Expert Meeting on Virtual Water Trade; IHE Delft Institute for Water Education: Delft, The Netherlands, 2003; Volume 12, pp. 1-244.

8. Jiang, W.L. Axiology of Water Resources; Science Press: Beijing, China, 1998.

9. Viala, E. Water for Food, Water for Life: A Comprehensive Assessment of Water Management in Agriculture. Irrig. Drain. Syst. 2008, 22, 127-129. [CrossRef]

10. Connor, R. Managing Water under Uncertainty and Risk: The United Nations World Water Development Report 4. United Nations World Water. 2012. Available online: https:/ / www.issuelab.org/resource/managing-water-under-unce (accessed on 13 July 2021).

11. Luo, P.; Sun, Y.T.; Wang, S.T.; Nover, D. Historical assessment and future sustainability challenges of Egyptian water resources management. J. Clean. Prod. 2020, 263, 121154. [CrossRef]

12. Wagener, T.; Sivapalan, M.; Troch, P.A.; McGlynn, B.L.; Harman, C.J.; Gupta, H.V.; Kumar, P.; Rao, P.S.; Basu, N.B.; Wilson, J.S. The future of hydrology: An evolving science for a changing world. Water Resour. Res. 2010, 46, W05301. [CrossRef]

13. Oreskes, N. How Earth Science Has Become a Social Science. Hist. Soc. Res. 2015, 2, $246-270$.

14. Pataki, D.E.; Carreiro, M.M.; Cherrier, J.; Grulke, N.E.; Jennings, V.; Pincetl, S.; Pouyat, R.V.; Whitlow, T.H.; Zipperer, W.C. Coupling biogeochemical cycles in urban environments: Ecosystem services, green solutions, and misconceptions. Front. Ecol. Environ. 2011, 9, 27-36. [CrossRef] 
15. Rasul, G.; Sharma, B. The nexus approach to water-energy-food security: An option for adaptation to climate change. Clim. Policy 2015, 16, 682-702. [CrossRef]

16. Sivapalan, M.; Savenije, H.H.G.; Blöschl, G. Socio-hydrology: A new science of people and water. Hydrol. Process. 2012, 26, 1270-1276. [CrossRef]

17. Elshafei, Y.; Sivapalan, M.; Tonts, M.; Hipsey, M.R. A prototype framework for models of socio-hydrology: Identification of key feedback loops with application to two Australian case-studies. Hydrol. Earth Syst. Sci. Discuss. 2014, 11, 629-689. [CrossRef]

18. Luan, J.K.; Zhang, Y.Q.; Tian, J.; Meresa, H.; Liu, D.F. Coal mining impacts on catchment runoff. J. Hydrol. 2020, 589, 125101. [CrossRef]

19. Zhang, L.P.; Huang, Q.; Liu, D.F.; Deng, M.J.; Zhang, H.X.; Pan, B.Z.; Zhang, H.G. Long-term and mid-term ecological operation of cascade hydropower plants considering ecological water demands in arid region. J. Clean. Prod. 2021, 279, 123599. [CrossRef]

20. Chen, Q.; Chen, D.; Li, R.; Ma, J.; Blanckaert, K. Adapting the operation of two cascaded reservoirs for ecological flow requirement of a de-watered river channel due to diversion-type hydropower stations. Ecol. Modell. 2013, 252, 266-272. [CrossRef]

21. Baldassarre, G.D.; Viglione, A.; Carr, G.; Kuil, L.; Salinas, J.L.; Blöschl, G. Socio-hydrology: Conceptualising human-flood interactions. Hydrol. Earth Syst. Sci. 2013, 17, 3295-3303. [CrossRef]

22. Srinivasan, V. Reimagining the past-Use of counterfactual trajectories in socio-hydrological modelling: The case of Chennai, India. Hydrol. Earth Syst. Sci. 2015, 19, 785-801. [CrossRef]

23. Van, E.; Li, Z.; Sivapalan, M.; Pande, S.; Kandasamy, J.; Savenije, H.; Chanan, A.; Vigneswaran, S. Socio-hydrologic modeling to understand and mediate the competition for water between agriculture development and environmental health: Murrumbidgee River basin, Australia. Hydrol. Earth Syst. Sci. 2014, 18, 4239-4259. [CrossRef]

24. Liu, Y.; Tian, F.; Hu, H.; Sivapalan, M. Socio-hydrologic perspectives of the co-evolution of humans and water in the Tarim River Basin, Western China: The Taiji-Tire Model. Hydrol. Earth Syst. Sci. 2014, 18, 1289-1303. [CrossRef]

25. Liu, D.F.; Tian, F.Q.; Lin, M.; Sivapalan, M. A conceptual socio-hydrological model of the co-evolution of humans and water: Case study of the Tarim River basin, western China. Hydrol. Earth Syst. Sci. 2015, 19, 1035-1054. [CrossRef]

26. Lu, Y.; Tian, F.Q.; Guo, L.Y.; Borzi, I.; Patil, R.; Wei, J.; Liu, D.F.; Wei, Y.P.; Yu, D.J.; Sivapalan, M. Socio-Hydrologic Modeling of the Dynamics of Cooperation in the Transboundary Lancang-Mekong River. Hydrol. Earth Syst. Sci. 2020, 25, 1883-1903. [CrossRef]

27. Halder, S.; Kumar, P.; Das, K.; Dasgupta, R.; Mukherjee, A. Socio-Hydrology Approach to Explore Groundwater-Human Wellbeing Nexus: Case Study from Sundarbans, India. Water 2021, 13, 1635. [CrossRef]

28. Kumar, P.; Avtar, R.; Dasgupta, R.; Johnson, B.A.; Mukherjee, A.; Ahsan, M.N.; Nguyen, D.C.H.; Nguyen, H.Q.; Mishra, B.K. Socio-hydrology: A key approach for adaptation to water scarcity and achieving human well-being in large riverine islands. Prog. Disaster Sci. 2020, 8, 100134. [CrossRef]

29. Liu, P.; Feng, M.Y.; Guo, S.L.; Li, Z.J. Methodologies and Challenges for Socio-Hydrology. J. Water Resour. Res. 2016, 5, 521-529. [CrossRef]

30. Assaf, H.; Hartford, D. Physically-based modelling of life safety considerations in water resource decision-making. ASCE EWRI World Water and Environmental Resources Congress. Bridging the Gap: Meeting the World's Water and Environmental Resources Challenges. In Proceedings of the World Water and Environmental Resources Congress, Salt Lake City, UT, USA, 27 June-1 July 2004. [CrossRef]

31. Chen, X.; Zhang, F.B. Agent-based modelling and simulation of urban evacuation: Relative effectiveness of simultaneous and staged evacuation strategies. J. Oper. Res. Soc. 2008, 59, 25-33. [CrossRef]

32. Dawson, R.J.; Peppe, R.; Miao, W. An agent-based model for risk-based flood incident management. Nat. Hazards 2011, 59, 167-189. [CrossRef]

33. Evans, T.P.; Kelley, H. Multi-scale analysis of a household level agent-based model of landcover change. J. Environ. Manage. 2004, 72, 57-72. [CrossRef]

34. Housh, M.; Cai, X.; Ng, T.L.; Mcisaac, G.F.; Ouyang, Y.; Khanna, M.; Sivapalan, M.; Jain, A.K.; Eckhoff, S.; Gasteyer, S. System of Systems Model for Analysis of Biofuel Development. J. Infrastruct. Syst. 2015, 21, 04014050. [CrossRef]

35. Yaeger, M.A.; Sivapalan, M.; Mcisaac, G.F.; Cai, X. Comparative analysis of hydrologic signatures in two agricultural watersheds in east-central Illinois: Legacies of the past to inform the future. Hydrol. Earth Syst. Sci. 2013, 17, 4607-4623. [CrossRef]

36. Yaeger, M.A.; Housh, M.; Cai, X.; Sivapalan, M. An integrated modeling framework for exploring flow regime and water quality changes with increasing biofuel crop production in the U.S. Corn Belt. Water Resour. Res. 2014, 50, 9385-9404. [CrossRef]

37. Emmerik, T.V.; Elshafei, Y.; Mahendran, R.; Kandasamy, J.; Pande, S.; Sivapalan, M. Alternative socio-centric approach for model validation-A way forward for socio-hydrology. In Proceedings of the 19th EGU General Assembly Conference Abstracts, Vienna, Austria, 23-28 April 2017.

38. Chen, Z.; Wei, S. Application of System Dynamics to Water Security Research. Water Resour. Manage 2014, 28, 287-300. [CrossRef]

39. Feng, M.; Liu, P.; Li, Z.; Zhang, J.; Liu, D.; Xiong, L. Modeling the nexus across water supply, power generation and environment systems using the system dynamics approach: Hehuang Region, China. J. Hydro. 2016, 543, 344-359. [CrossRef]

40. Sivapalan, M.; Blöeschl, G. Time scale interactions and the coevolution of humans and water. Water Resour. Res. 2015, 51, 6988-7022. [CrossRef]

41. El-Gafy, I.K. System Dynamic Model for Crop Production, Water Footprint, and Virtual Water Nexus. Water Resour. Manag. 2014, 28, 4467-4490. [CrossRef] 
42. Feng, Z.K.; Niu, W.J.; Cheng, C.T. China's large-scale hydropower system: Operation characteristics, modeling challenge and dimensionality reduction possibilities. Renew. Energ. 2019, 136, 805-818. [CrossRef]

43. Herrera-Franco, G.; Montalván-Burbano, N.; Carrión-Mero, P.; Bravo-Montero, L. Worldwide Research on Socio-Hydrology: A Bibliometric Analysis. Water 2021, 13, 1283. [CrossRef]

44. Tian, F.Q.; Cheng, T.; Lu, Y.; Xu, Z.X. A review on socio-hydrology and urban hydrology. Prog. Geo. 2018, 37, 46-56. [CrossRef]

45. Ding, J.Y.; Zhao, W.W.; Fang, X.N. Advances in social hydrology. Chin. J. Appl. Ecol. 2015, 26, 1055-1063. [CrossRef]

46. Xia, J.; Zhang, X.; Wei, F.L.; Wang, Q.; She, D.; Xu, J. Water system theory and its practices in China. South-to-North Water Transf. Water Sci. Technol. 2018, 16, 1-13. [CrossRef]

47. Sawada, Y.; Hanazaki, R. Socio-hydrologic data assimilation: Analyzing human-flood interactions by model-data integration. Hydrol. Earth Syst. Sci. 2020, 1-54. [CrossRef]

48. Dang, Q.; Konar, M. Trade Openness and Domestic Water Use. Water Resour. Res. 2018, 54, 4-18. [CrossRef]

49. Mostert, E. An alternative approach for socio-hydrology: Case study research. Hydrol. Earth Syst. Sci. 2018, 22, 317-329. [CrossRef]

50. Baldassarre, G.D.; Viglione, A.; Carr, G.; Kuil, L.; Yan, K.; Brandimarte, L.; Blschl, G. Debates-Perspectives on socio-hydrology: Capturing feedbacks between physical and social processes. Water Resour. Res. 2015, 51, 4770-4781. [CrossRef]

51. Li, Z.; Wang, J.; Liu, Z.; Meng, X.; Heino, J.N.; Jiang, X.; Xiong, X.; Jiang, X.; Xie, Z. Different responses of taxonomic and functional structures of stream macroinvertebrate communities to local stressors and regional factors in a subtropical biodiversity hotspot. Sci. Total Environ. 2019, 655, 1288-1300. [CrossRef]

52. Li, Z.; Liu, Z.; Heino, J.N.; Jiang, X.; Wang, J.; Tang, T.; Xie, Z. Discriminating the effects of local stressors from climatic factors and dispersal processes on multiple biodiversity dimensions of macroinvertebrate communities across subtropical drainage basins. Sci. Total Environ. 2020, 711, 134750. [CrossRef] [PubMed]

53. Wei, X.; Liu, D.F.; Liu, H.; Li, M.; Lin, M.; Huang, Q. Analysis of socio-economic driving forces of cultivated land area and its forecast in the upstream of Han River of China. IOP Conf. Ser. Earth Environ. Sci. 2018, 189, 052037. [CrossRef]

54. Xia, J.; Ma, X.Y.; Zou, L.; Wang, Y.L.; Jing, Z.X. Quantitative analysis of the effects of climate change and human activities on runoff in the Upper Hanjiang River basin. South-to-North Water Transf. Water Sci. Technol. 2017, 15, 1-6. (In Chinese) [CrossRef]

55. Yang, Q.; Liu, D.F.; Meng, X.M.; Huang, Q.; Lin, M. Quantitative analysis of impacts of environment changes on runoff in upper Han River. J. Hydroelectr. Eng. 2019, 38, 73-84. (In Chinese) [CrossRef]

56. Wei, X.; Liu, D.F.; Luan, J.K.; Li, M.; Lin, M. Analysis of the Changing Laws and Influencing Factors of Social and Economic Indicators in the Upper Reach of Han River Basin. Univers. J. Geosci. 2018, 6, 55-64. [CrossRef]

57. Jia, B.; Zhou, J.; Zhang, Y.; Tian, M.; Ding, X. System Dynamics Model for the Coevolution of Coupled Water Supply-Power Generation-Environment Systems: Upper Yangtze River Basin, China. J. Hydrol. 2020, 593, 125892. [CrossRef]

58. Li, B.; Sivapalan, M.; Xu, X. An Urban Sociohydrologic Model for Exploration of Beijing's Water Sustainability Challenges and Solution Spaces. Water Resour. Res. 2019, 55, 5918-5940. [CrossRef]

59. The Implementation Opinions of the General Office of Shaanxi Provincial People's Government on Strictly Protecting Cultivated Land and Resolutely Stopping the "Non-Agricultural" Behavior of Cultivated Land. Available online: http:/ / zrzyt.shaanxi.gov. cn/info/1150/51238.htm (accessed on 12 August 2021).

60. Regulations for the Implementation of the Land Administration Law of the People's Republic of China. Available online: http:/ / zrzyt.shaanxi.gov.cn/info/1148/54120.htm (accessed on 12 August 2021).

61. Notice of Shaanxi Provincial People's Government on Printing and Distributing Population Development Plan (2016-2030). Available online: http://www.shaanxi.gov.cn/zfxxgk/zfgb/2018_3966/d5q_3971/201803/t20180320_1638241.html (accessed on 12 August 2021).

62. Wei, J.; Zheng, K.; Zhang, F.; Fang, C.; Zhou, Y.; Li, F.; Jian, S. Migration of Rural Residents to Urban Areas Drives Grassland Vegetation Increase in China's Loess Plateau. Sustainability 2019, 11, 6764. [CrossRef] 